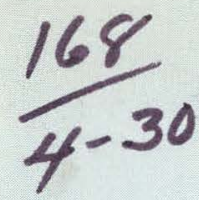

AEC RESEARCH AND DEVELOPMENT REPORT

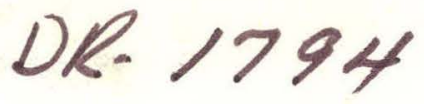

Y-1758

Engineering and Equipment

\title{
ASPECTS OF THE BRITTLE FRACTURE FAILURE OF A 30-INCH-ID, 30,000-PSI ISOSTAT WITH THREADED CLOSURE
}

\section{UNION CAREIDE CORPORATION NUCLEAR DIVISION OAK RIDGE Y-12 PLANT}

operated for the ATOMIC ENERGY COMMISSION under U. S. GOVERNMENT Contract W-7405 eng 26

UNION

CARBIDE
OAK RIDGE Y-12 PLANT

P. O. BOX $Y$

OAK RIDGE, TENNESSEE 37830 


\section{DISCLAIMER}

This report was prepared as an account of work sponsored by an agency of the United States Government. Neither the United States Government nor any agency Thereof, nor any of their employees, makes any warranty, express or implied, or assumes any legal liability or responsibility for the accuracy, completeness, or usefulness of any information, apparatus, product, or process disclosed, or represents that its use would not infringe privately owned rights. Reference herein to any specific commercial product, process, or service by trade name, trademark, manufacturer, or otherwise does not necessarily constitute or imply its endorsement, recommendation, or favoring by the United States Government or any agency thereof. The views and opinions of authors expressed herein do not necessarily state or reflect those of the United States Government or any agency thereof. 


\section{DISCLAIMER}

Portions of this document may be illegible in electronic image products. Images are produced from the best available original document. 
Printed in the United States of America. Available from

National Technical Information Service

U.S. Department of Commerce, Springfield, Virginia 22151

Price: Printed Copy $\$ 3.00$; Microfiche $\$ 0.65$

This report was prepared as an account of work sponsored by the United States Government. Neither the United States nor the United States Atomic Energy Commission, nor any of their employees, nor any of their contractors, subcontractors, or their employees, makes any warranty, express or implied, or assumes any legal liability or responsibility for the accuracy, completeness or usefulness of any information, apparatus, product or process disclosed, or represents that its use would not infringe privately owned rights. 
Date Issued: April 30, 1971

\title{
UNION CARBIDE CORPORATION Nuclear Division
}

\section{OAK RIDGE Y-12 PLANT}

Operated under Contract W-7405-eng-26

With the US Atomic Energy Commission

\section{ASPECTS OF THE BRITTLE FRACTURE FAILURE OF A 30-INCH-I'D, 30,000-PSI ISOSTAT WITH THREADED CLOSURE}

\author{
H. A. Pohto
}

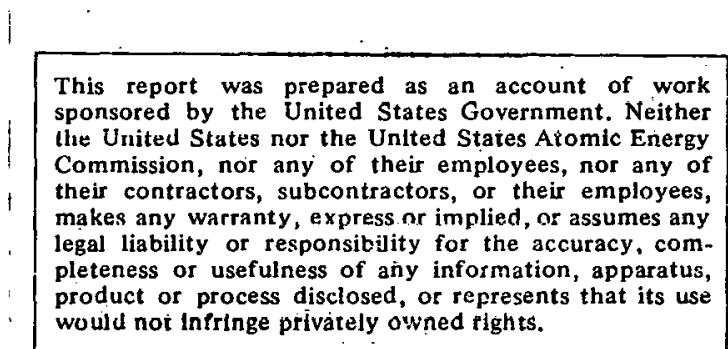

Oak Ridge, Tenncsisec 
Document $\quad \mathrm{Y}-1758$

TID -4500

DISTRIBUTION

Atomic Energy Commission

Keller, C. A.

Zachry, D. S., Jr

Battelle Memorial Institute

Boyer, C. B.

Harwood Engineering Company.

Newhall, D. H.

Oak Ridge Gaseous Diffusion Plant

Jordan, R. G.

Wilcox, W. J., Jr

Oak Ridge Y-12 Plant

Alvey, H. E. Bell, B. B.

Bernander, N.K.

Burditt, R. B.

Burkhart, L. E.

Butturini, W. G.

Choat, E. E.

Denny, A. (2)

Ebert, J. W.

Ellingson, R. D.

Evans, G. W.

Foulk, D. L.
Gritzner, V. B. Haeusler, K. R. Hemphill, L. F. Hensley, C. E. Hodges, J. W. Huber, R. A. Huddleston, R. L. Jackson, V.C. Kahl, K. G. Keith, Alvin Kite, H. T. Lambert, F. J., Jr Long, $P$. J. Marrow, G. B. McLendon, J. D. Mitchel, G.W. Muzzali, C.E.

Perry, A. E.

Pohto, H. A. (50)

Ross, W. D.

Smith, H. F., Jr

Smith, R. D.

Stoner, H. H.

St Onge, C. D.

Sturm, R. G. (consultant)

Thompson, J. C., Jr

Tilson, F. V.

Trotter, T. C.

Valentine, C, K.

Weathersby, W. E. (2)

Wesley, R. L.

Williams, R. D.

Williamson, R. A.

Yaggi, W. J.

$Y-12$ Central Files (5)

$Y-12$ Central Files (master copy)

$Y-12$ Central Files (route)

$Y-12$ Central Files $(Y-12 R C)$ 
Paducah Gaseous Diffusion Plant

Winkel, R. A.

Struthers Nuclear and Process Company

Waite, H. H.

Watervliet Arsenal (US Army)

Davidson, T. E.

In addition, this report is distributed in accordance with the category UC-38, Engineering and Equipment, as given in the "USAEC Standard Distribution Lists for Unclassified Scientific and Technical Reports", TID-4500. 
At the Oak Ridge Y-12 Plant, a 30 -inch-ID by 120-inch-deep, vertical-standing isostat, designed for a 30,000-psi operating pressure, ruptured abruptly during its 1,554 th cycle of operation. This pressure vessel was of multiwall, threaded-closure construction. It was ascertained that a brittle fracture occurred, originating at the root of the first thread of the lower closure. A thorough study was made of the factors that contributed to the failure and a comparison was made of the calculated stresses of a post-failure analysis to the actual stress-strain data obtained from the root of the threads of a vessel considered to be a "twin" of the fractured isostat. Progress in the state of the art of experimental stress analysis made these data re cently obtainable. Comparisons between the calculated and experimental stresses are considered remarkable and would have predicted imminent failure at the operating pressure. 
CONTENTS

SUMMARY ........................ . 6

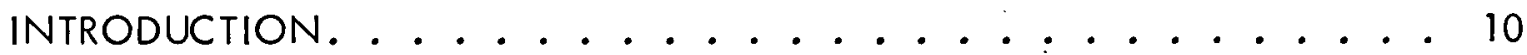

A STUDY OF THE BRITTLE FRACTURE FAILURE . . . . . . . . . . . 13

Analysis of the Thread Loads and Stresses. . . . . . . . . . . 13

Thread-Load Derivation (Sturm method). . . . . . . . . . 13

Thread-Load Calculation for Pressure Vessel I (ruptured vessel). . . . . 18

Thread-Load Calculation for Pressure Vessel II (twin vessel) . . . . . . 20

Thread Internal Stress (Boussinesq shear stress method). . . . . . . 22

Shell Tensile Stress at the First Thread (direct-plus-bending stress method) . . . . . . . . . . . . . 23

Experimental Strain Gage Analysis . . . . . . . . . . . . . 24

Preface ........................ 24

Installation of the Gages... . . . . . . . . . . . 25

Obtaining the Strain Data . . . . . . . . . . . . 32

Strain Gage Data Results. . . . . . . . . . . . . 32

Conclusions and Recommendations. . . . . . . . . . . . . 34

REFERENCES. . . . . . . . . . . . . . . . . 37

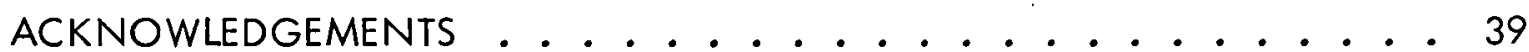




\section{SUMMARY}

A 30-inch-ID by 120-inch-deep pressure vessel, designed to operate at 30,000 psi, ruptured during its 1,554 th cycle of operation. It was ascertained that a brittle fracture occurred which originated at the root of the first thread of the lower closure.

The following points are considered of paramount significance as the result of a postfailure analysis and study of the failure:

1. The average strain-gage values, obtained from a vessel of similar design at a 22,500 -psi operating pressure, gave a stress of 102,000 psi. This value is comparable to the alternating stress range of 103,000 psi calculated by the directplus-bending stress method.

2. For a 30,000-psi operating pressure and using the same direct-plus-bending stress method mentioned in Point 1, a 74,500-psi alternating stress component $\left(S_{a}\right)$ was calculated for the first thread root of the ruptured vessel. This value was interpreted as being equivalent to 1,300 cycles of fatigue life from the ASME Section VIII, Division 2, Design Fatigue Curve. (1) Using the thread loads obtained by the Sturm method, (2) a Boussinesq shear stress was calculated as 88,200 psi at the same location and interpreted as 800 cycles of fatigue life (see Figures 1 and 2 ).

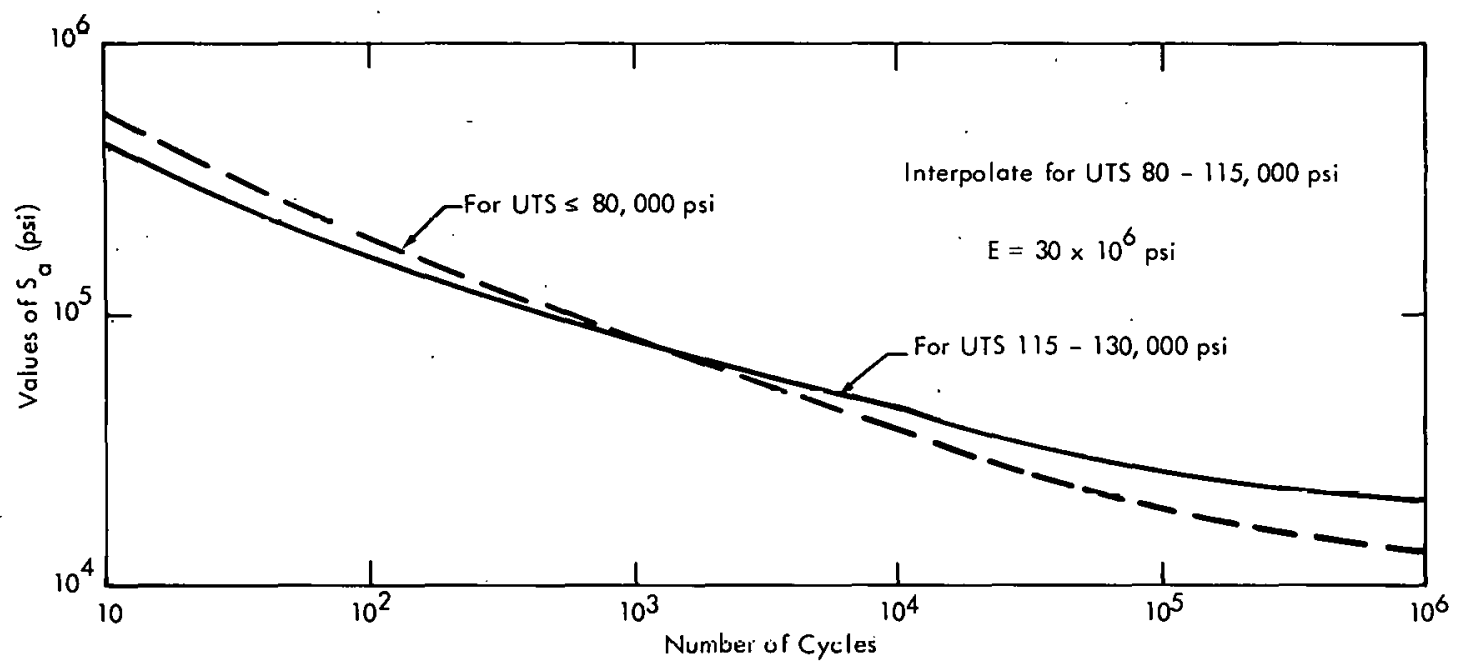

Figure 1. DESIGN FATIGUE CURVES FOR CARBON, LOW ALLOY, SERIES 4XX; HIGH-ALLOY STEE LS, AND HIGH-TENSILE STEELS FOR TEMPERATURES NOT EXCEEDING $700^{\circ} \mathrm{F}$. (Taken from ASME Section VIII, Division 2, Figure 5-110.1)

3. Photoelastic stress analyses (3) of a scale model of the pressure-vessel closures were made that indicated a stress concentration factor greater than 3.0; Peterson's (4) 


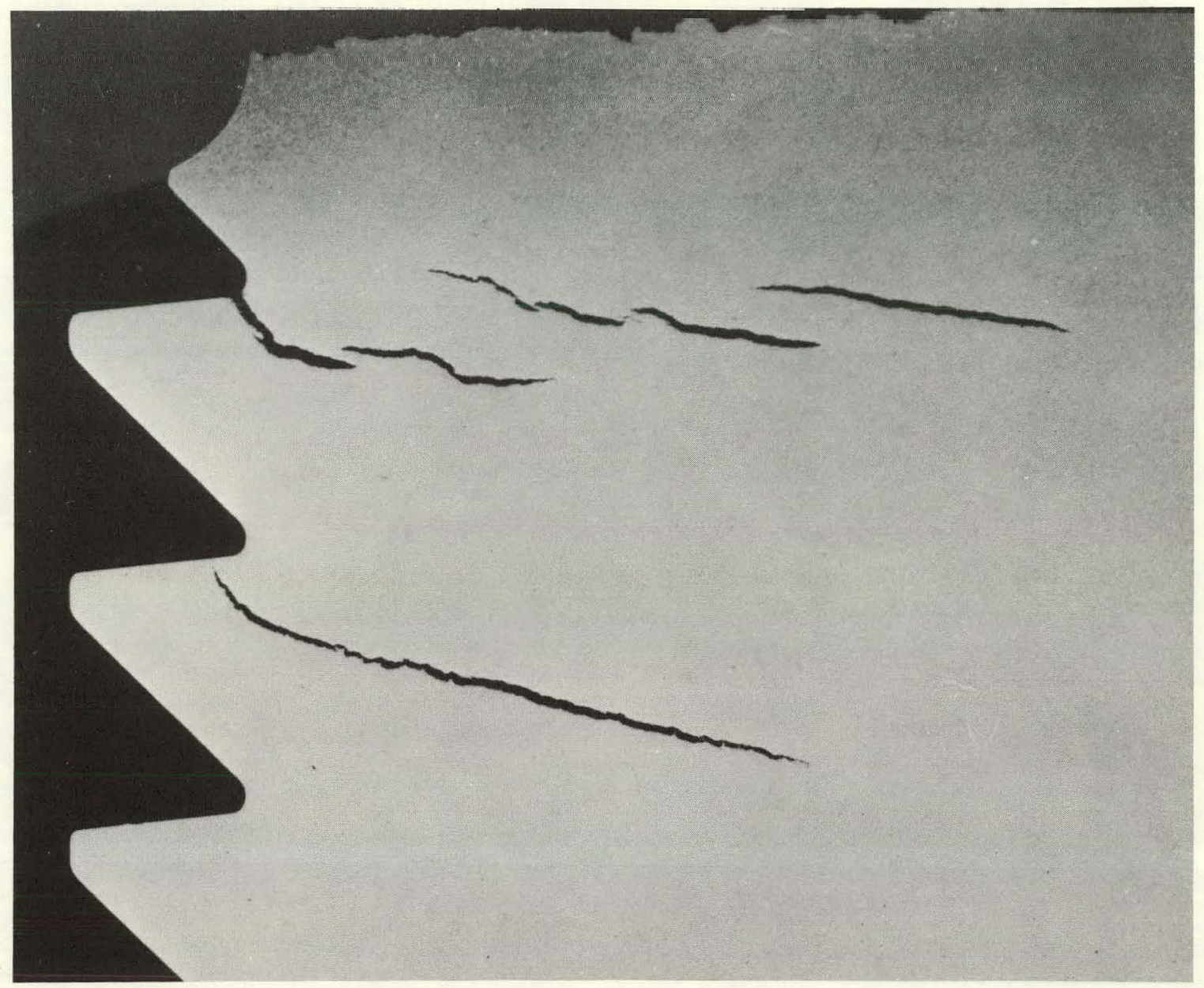

137818

Figure 2. BOUSSINESQ SHEAR. (Actual Illustration for Pressure Vessel I Failure)

curves indicated a stress concentration factor of 3.5 for the ruptured vessel and 3.7 for the "twin" vessel.

4. The root of the first thread revealed an "orange peel" surface caused from autofretteging that highly strained area as a result of the 45,000-psi pressure test by the manufacturer. As shown by the Bauschinger effect curve(5) (Figure 3), a possible 50,000-psi compressive residual stress remained. Thus, for the remaining cycles at a 22,500-psi pressure, a tensile stress approximately 50,000 psi less than the total measured $(102,000$ psi) or calculated stress range would occur.

5. At failure, the temperature of the ruptured vessel's wall was approximately $60^{\circ} \mathrm{F}$. The nil-ductility temperature of the steel in this vessel was $130^{\circ} \mathrm{F}$. The pressure vessel was constructed from nickel-moly steel forgings with a yieldstrength value of 96,000 psi and an ultimate tensile strength of 115,000 psi. 


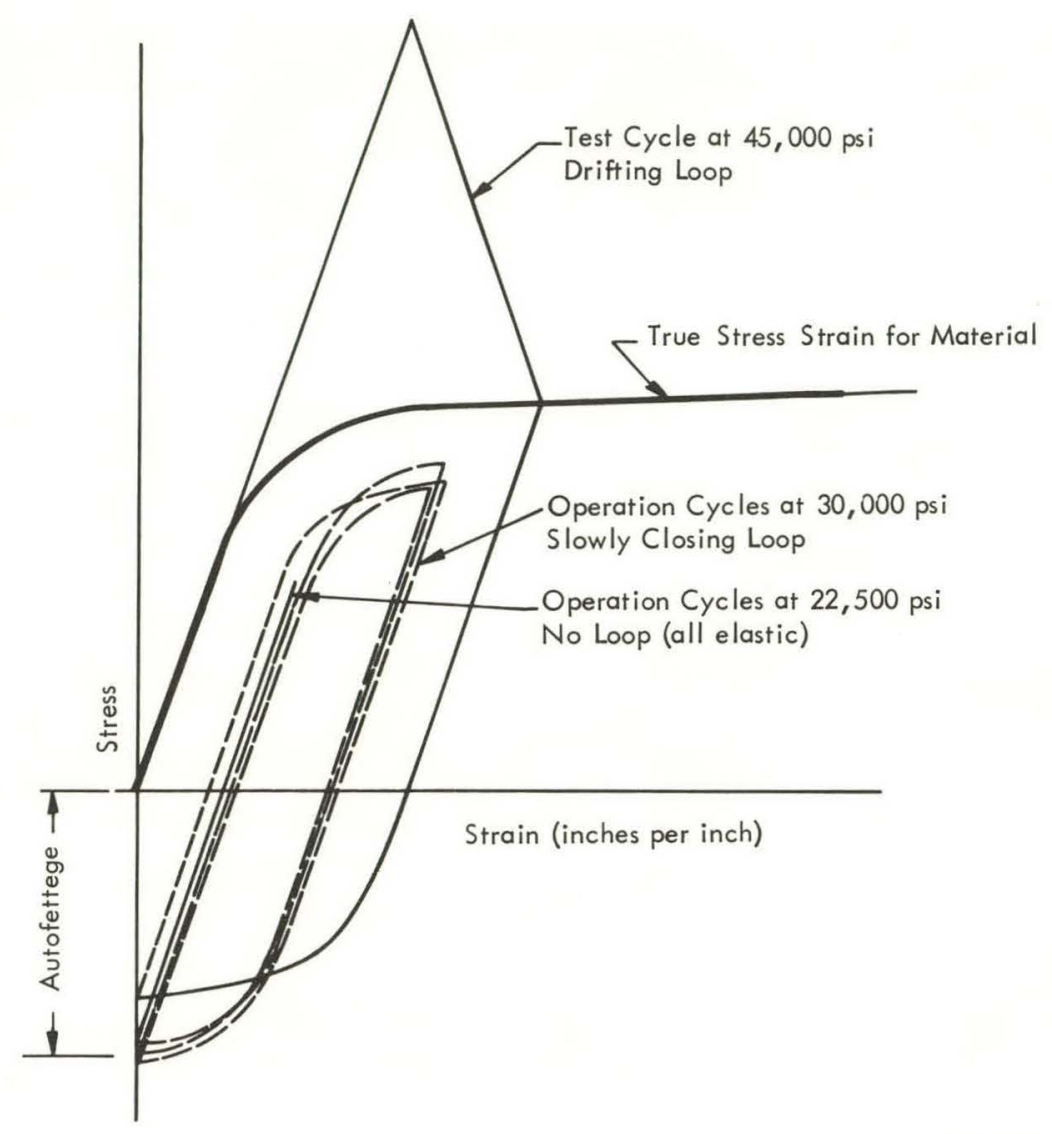

$1378 \times 7$

Figure 3. BAUSCHINGER EFFECT CURVE. (Illustrative Only)

6. Matching steps at the interface of the shrunk-fit multiwall shells were located in the upper section of the vessel. By monitoring the "twin" vessel(6) it was detected that a sudden shock loading occurs at the lower closure. The shrink-fit friction may have been overcome by the vertical force on the lower closure and its seal, or a sudden slippage of the bridgeman-type lower seal may have occurred. This shock was detected at various operating pressures between 4,000 and 22,000 psi. The shock impulses caused stress intensities up to 1,500 psi of 50 to 300 microseconds duration. Shock loads occurring at higher operating pressures could be significant with respect to the service life.

7. It was ascertained that a brittle failure had occurred. This conclusion was substantiated by the following: (1) the operating temperature of the vessel with respect to the nil-ductility temperature of the material of construction; (2) the character of the break and its resultant fragments (Figures 4 and 5); (3) the lack of evidence of ductility (elongation) of the ruptured shell in the fracture area; and (4) the occurrence of shock loading. 


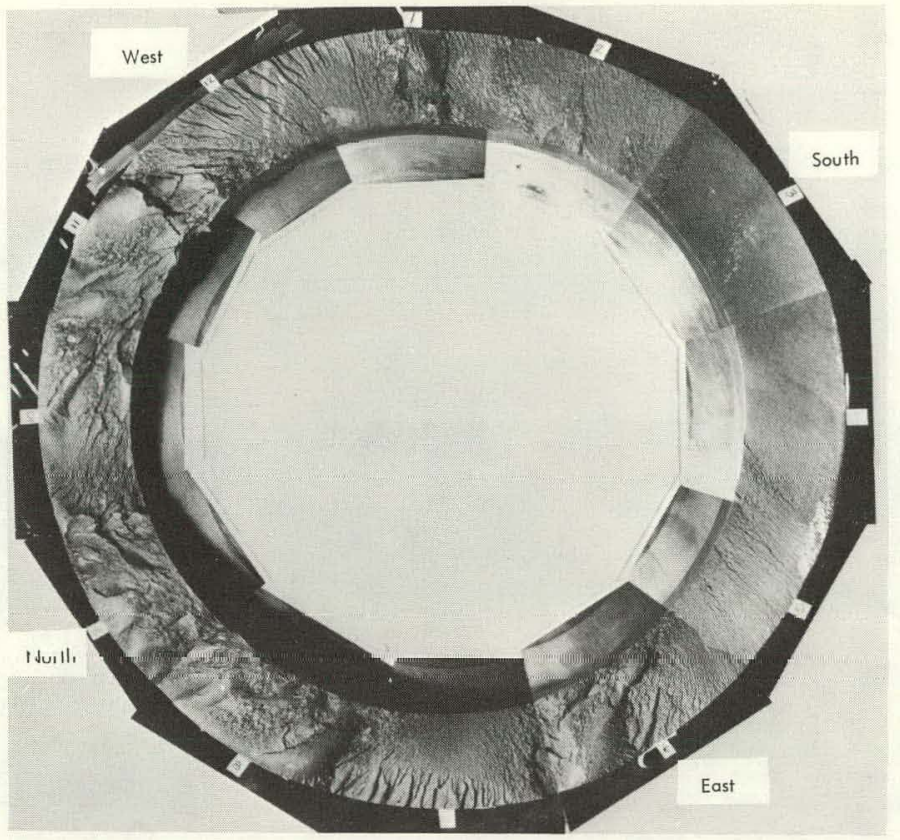

137817

Figure 4. FRACTURE FACE. (Top Section)

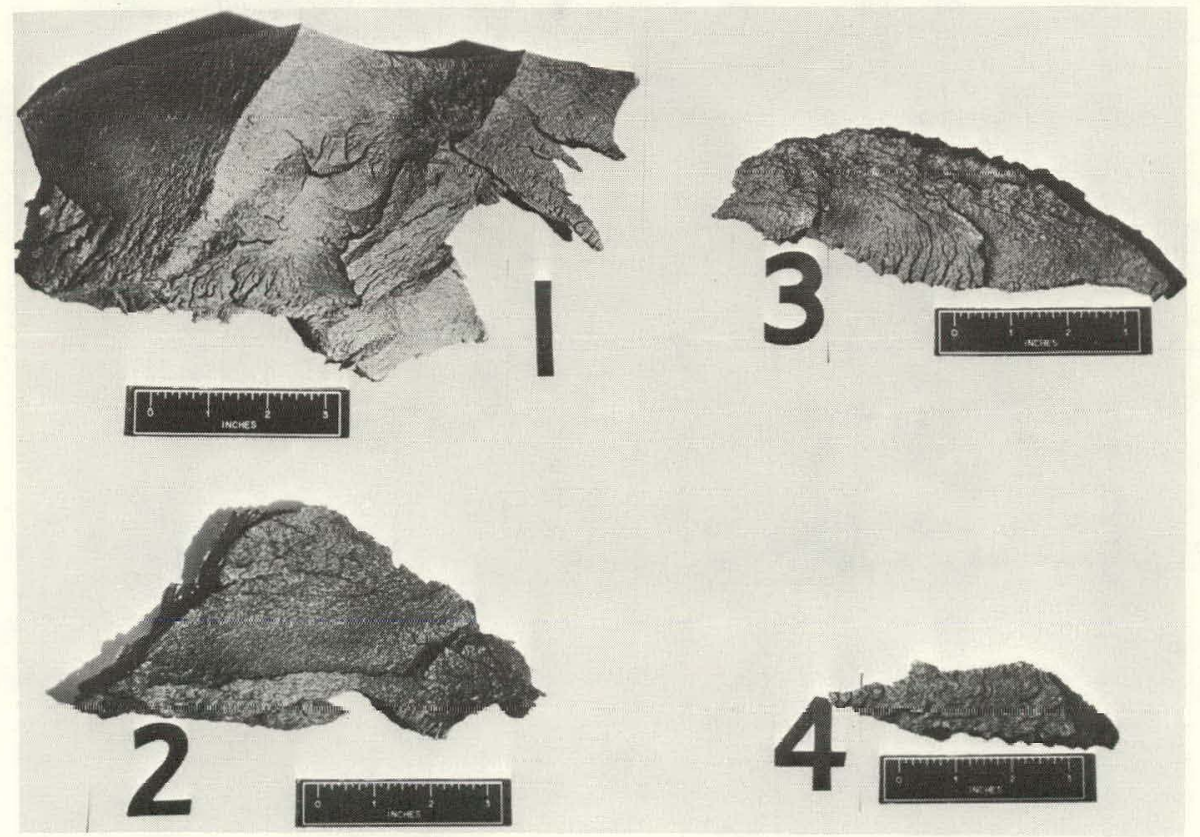

137820

Figure 5. FRAGMENTS FROM THE PRESSURE VESSEL LAILURE. 


\section{INTRODUCTION}

Several years ago, a 30-inch-ID by 120-inch-deep isostat, designed for a 30,000psi operating pressure, using mineral oil at ambient temperatures, was placed in operation at the Oak Ridge Y-12 Plant(a) (Figure 6). At the time, this vessel was believed to be the largest of its kind operating at this pressure.

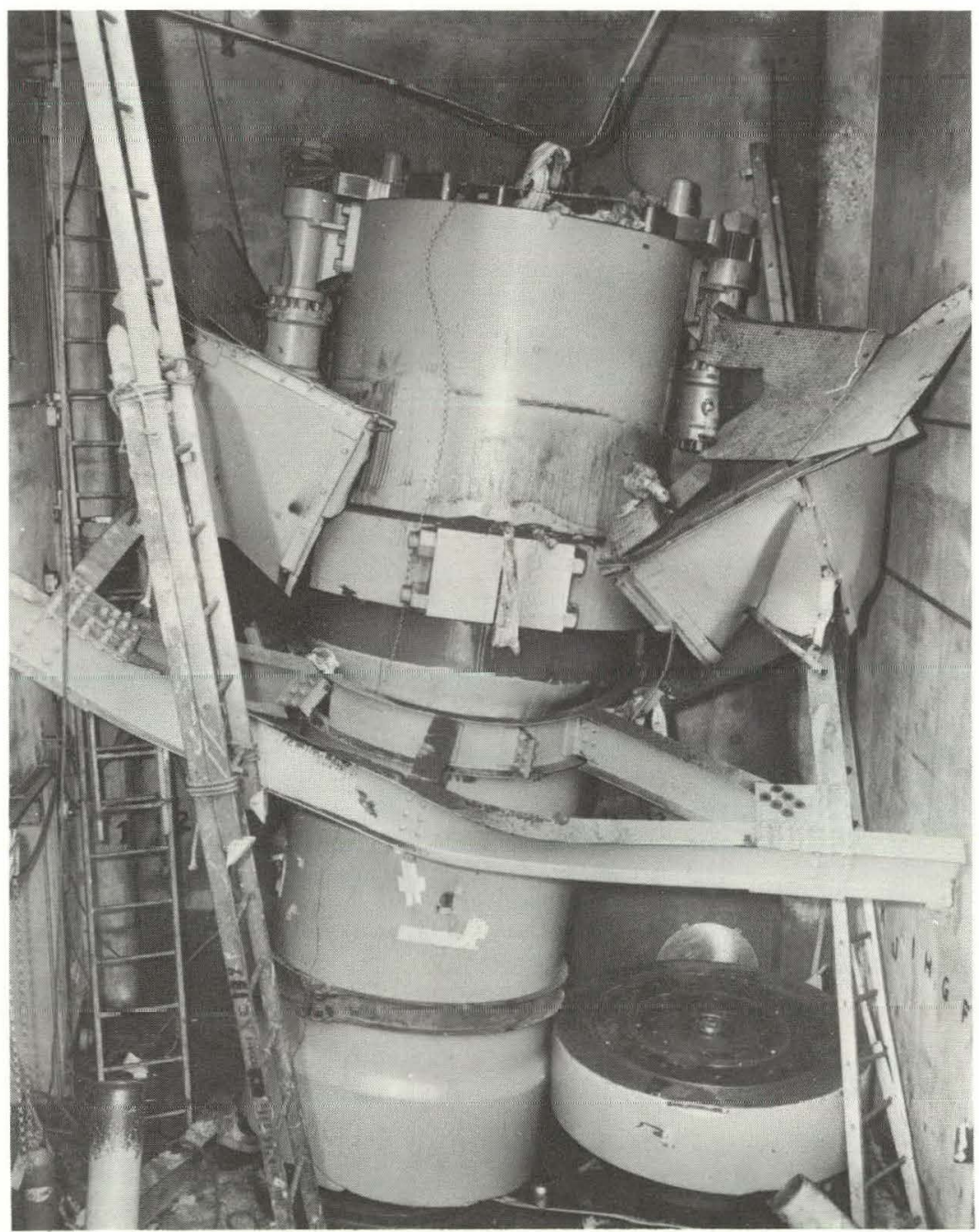

137819

Figure 6. FAILED PRESSURE VESSEL. (Showing Damage to the Vessel and the Containment Cell Area)

(a) Operated by the Union Carbide Corporation's Nuclear Division for the US Atomic Energy Commission. 
This pressure vessel was of multiwall, threaded-closure construction. The upper closure was a breech type with an interrupted buttress thread; the lower closure was a continuous buttress thread.

The pressure vessel ruptured abruptly during its 1,554th cycle, at an operating pressure of $28,500 \mathrm{psi}$. The failure occurred at the lower closure in the root of the first thread next to the pressure. A post-failure analysis of the stresses in the root of this thread revealed that failure could have been predicted.

Some years later, when the technology of experimental stress analysis had progressed to the point at which miniature strain gages became available, actual stress-strain data were obtained from an isostat considered to be basically identical to the ruptured vessel. This "twin" vessel was being installed when the first vessel ruptured (Figures 7 and 8).
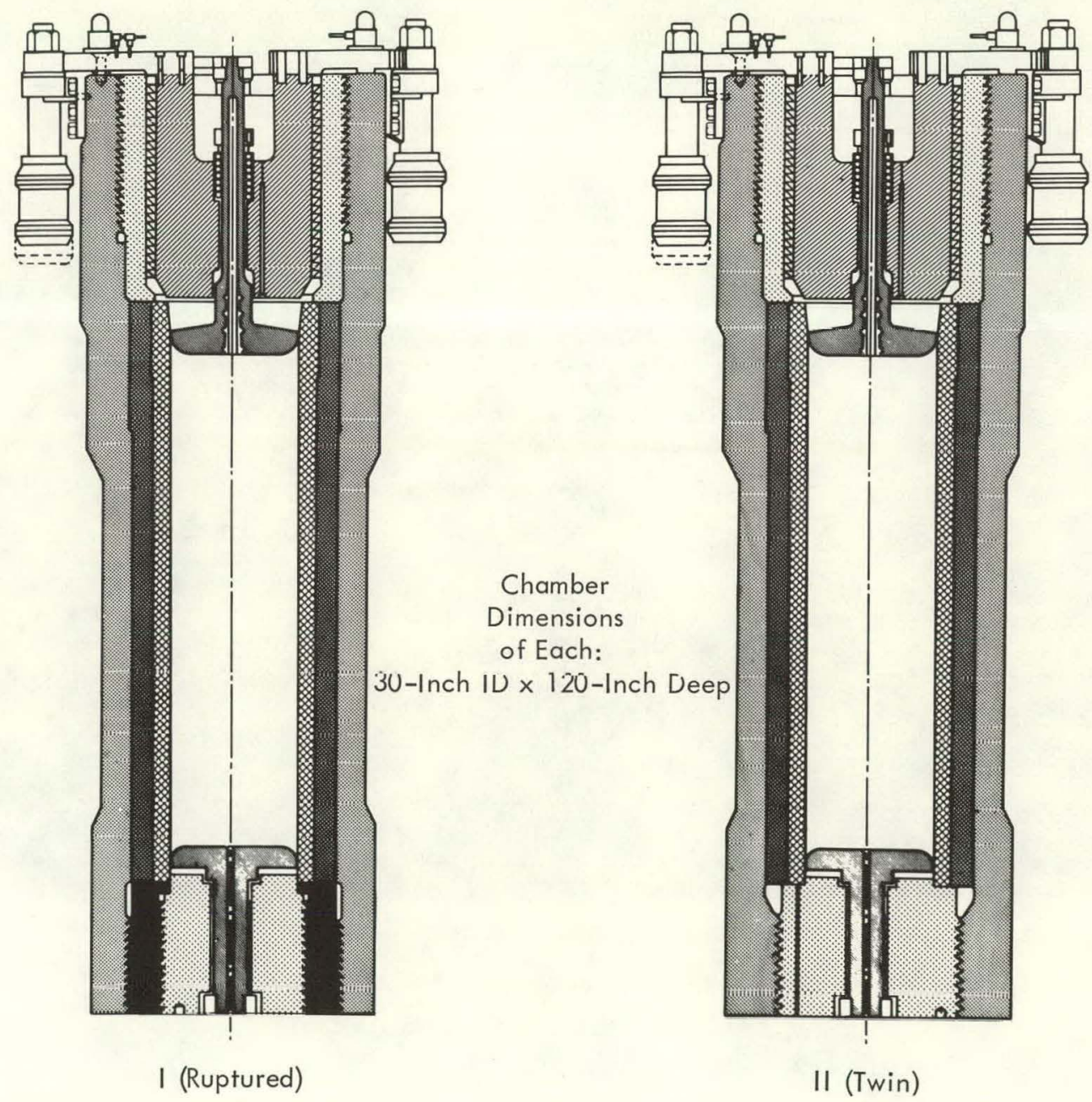

Figure 7. PRESSURE VESSELS I AND II. 


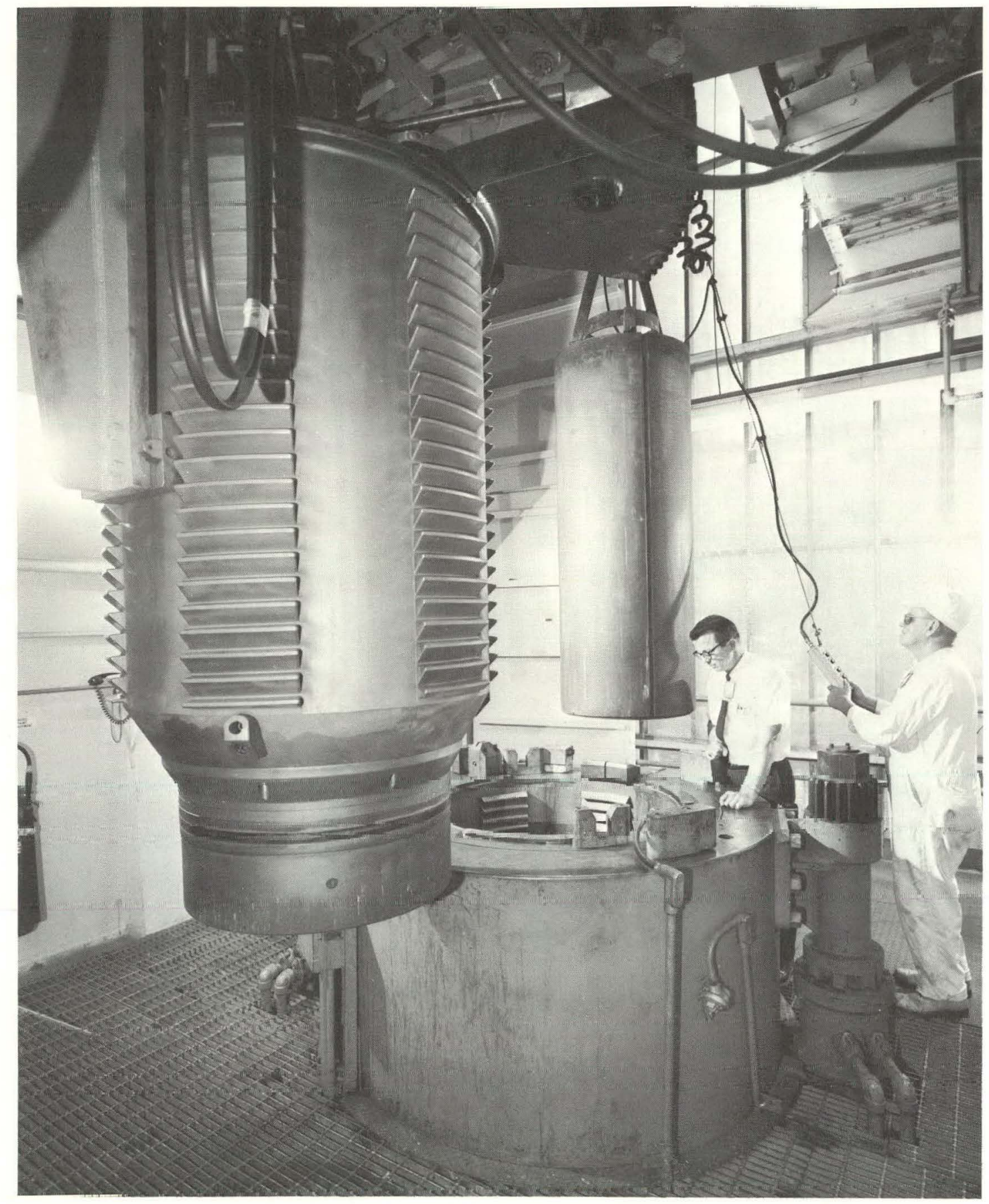

131732

Figure 8. UPPER CLOSURE OF PRESSURE VESSEL II.

Calculated and experimentally obtained stresses were comparable for the new vessel. Methods for the stress calculations and the method for obtaining the experimental data, along with other aspects of the failure, are discussed in this presentation. 


\section{A STUDY OF THE BRITTLE FRACTURE FAILURE}

\section{ANALYSIS OF THE THREAD LOADS AND STRESSES}

\section{Thread-Load Derivation (Sturm method)}

In the principle of thread-load analysis, R. G. Sturm (2) states that: "the load on any thread is that load which will cause a shear deformation in the thread sufficient to reconcile the tensile strain in the shell and the compressive strain in the plug". This expression can be represented as:

$$
e_{s}-e_{\dot{p}}=e_{t},
$$

where:

$e_{f}$ represents the sum of the deformations of both the thread in the plug and in the shell in one pitch length,

$e_{s}$ the tensile stretch of the shell at the threads in one pitch length, and

$e_{p}$ the compressive shortening of the plug at the threads in one pitch length.

These changes in length may be evaluated at each thread successively starting with the first thread next to the pressure.

In the shell, the tensile stress at the first thread is therefore: $(7)$

$$
\sigma_{z_{1}}=\frac{P}{A}+\frac{M_{1} Y_{1}}{I}
$$

where:

$P_{1}$ represents the load in the shell at the first thread for one inch of length at the pitch radius,

A the area of the cross section of the shell subtended by one inch of thread length at the pitch radius (see Figure 9),

$w$ the distance from the centroid of " $A$ " to the midpoint of the thread,

$M_{1}$ the moment in the shell at the first thread (also equal to $K P_{1} w$ ), 


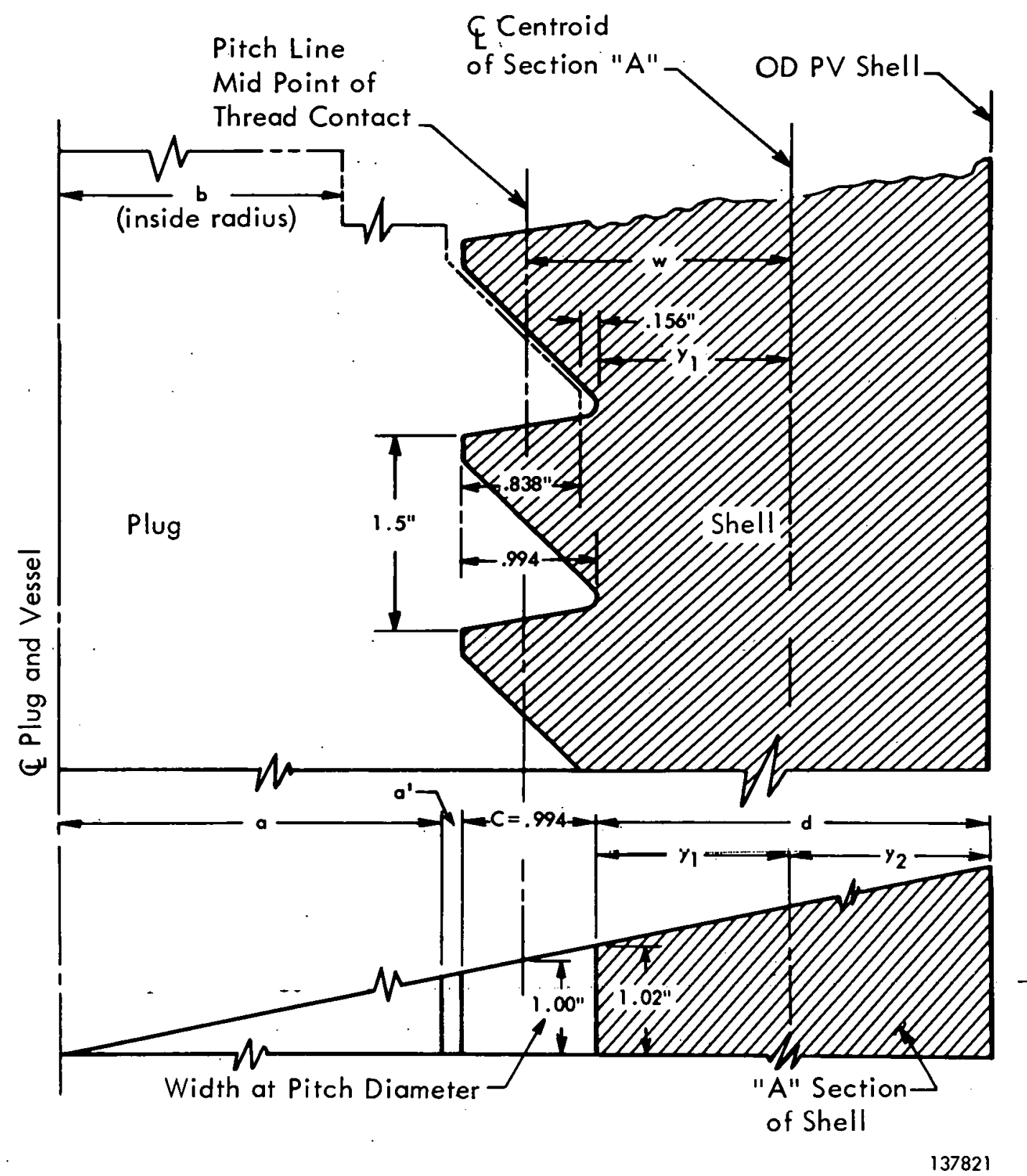

Figure 9. DIMENSIONAL DEFINITION OF TERMS.

$K$ the portion of the total moment carried by the thread section of the shell, (8)

$y_{1}$ the distance from the centroid of the shell section to the root of the shell thread,

$r$ the radius of gyration of Section $A$, and

I the moment of inertia of the shell of Section $A$ (also equal to $\mathrm{Ar}^{2}$ ). 
Therefore:

$$
\sigma_{z_{1}}=\frac{P_{1}}{A}\left(1+\frac{K w y_{1}}{r^{2}}\right) .
$$

For convenience, let $Q$ accumulate constants. Thus:

$$
Q=\frac{1}{A}\left(1+\frac{K w y_{1}}{r^{2}}\right) .
$$

Therofore:

$$
\sigma_{z_{1}}=Q P_{1}
$$

Let:

$F_{1}$ represent the load carried by the first thread for one inch of length at the pitch radius,

$P_{n}$ the load in the shell at the nth thread location, $F_{n}$ the load in the thread at the nth location for one inch of length at
the pitch radius,

$\sigma_{z_{n}}$ the uniaxial stress in the $n$th thread, and

$\sum F_{n-1}$ the sum of all the loads in the threads prior to $F_{n}$.

And let:

$$
\begin{gathered}
P_{n}=P_{1}-\sum F_{n-1}, \text { and } \\
\sigma_{z_{n}}=Q P_{n} .
\end{gathered}
$$

Therefore:

$$
\sigma_{z_{n}}=Q P_{1}-Q \Sigma F_{n-1}
$$

The unit strain, $\epsilon_{s n^{\prime}}$ in the shell at the $n$th thread is: 


$$
\epsilon_{s n}=\frac{\sigma_{n}}{E}=\frac{Q P_{1}}{E}-\frac{Q \Sigma F_{n-1}}{E}
$$

The total strain, $e_{s n^{\prime}}$ in the shell at the nth thread for a pitch length of " $L "$ is:

$$
e_{s n}=\epsilon_{s n} L=\left(P_{1}-\Sigma F_{n-1}\right) \frac{Q L}{E},
$$

where:

E represents the modulus of elasticity.

In the plug, the following development applies: .

Total force, $U$, in the plug is:

$$
U=\sigma_{i} \pi b^{2}
$$

where:

$\sigma_{i}$ represents the internal pressure, and

$b$ the inside radius of the pressure vessel.

The compressive stress, $\sigma_{\mathrm{p}_{1}}{ }^{\prime}$ in the plug at the first thread is given by:

$$
\sigma_{P_{1}}=\frac{U}{\pi a^{2}}=\frac{\sigma_{i} \pi b^{2}}{\pi a^{2}}=\sigma_{i} \frac{b^{2}}{a^{2}},
$$

where:

a represents the radius of the plug to the root of the plug thread, and

$R$ the pitch radius.

In successive thread-load determinations, the sum of all the previous thread loads is subtracted from the plug load. Thus, $U_{n}$, the plug load at the $n$th thread, is expressed by:

$$
U_{n}=\left(U-2 \pi R \Sigma F_{n-1}\right),
$$

and the stress in the plug, $\sigma_{p_{n}}$, at the nth thread written as: 


$$
\begin{gathered}
\sigma_{P_{n}}=\frac{U_{n}}{\pi a^{2}}=\frac{U-2 \pi R \sum F_{n-1}}{\pi a^{2}}=\frac{\sigma_{i} \pi b^{2}-2 \pi R \sum F_{n-1}}{\pi a^{2}}, \text { or } \\
\sigma_{P_{n}}=\frac{\sigma_{i} b^{2}}{a^{2}}-\frac{2 R \sum F_{n-1}}{a^{2}}=\frac{b^{2}}{a^{2}}\left(\sigma_{i}-\frac{2 R \sum F_{n-1}}{b^{2}}\right) .
\end{gathered}
$$

The unit compressive strain, $\epsilon_{p n^{\prime}}$ in the plug at the root of the $n$th thread is given by:

$$
\begin{gathered}
\epsilon_{P_{n}}=\frac{\sigma_{P_{n}}}{E} \text {, or } \\
\epsilon_{p_{n}}=-\left(\sigma_{i}-\frac{\sum F_{n-1} 2 R}{b^{2}}\right) \frac{b^{2}}{a^{2} E},
\end{gathered}
$$

and the total compressive strain in one pitch length, $L$, at the nth thread is written as:

$$
e_{p_{n}}=-\left(\epsilon_{p_{n}} L\right)=-\left(\sigma_{i}-\frac{\sum F_{n-1} 2 R}{b^{2}}\right) \frac{b^{2} L}{a^{2} E}
$$

The total strain or deflection with identical plug and shell threads with a thread load of $F_{n}$ is twice the shear deflection of one thread, (2) and the average shearing stress, $S_{s}$, with a thread thickness " $l$ " at the pitch.line of the thread is shown by:

$$
S_{s}^{\prime}=1 / 2 \frac{F_{n}}{l}
$$

and the shearing strain, $\epsilon_{s}$, for one thread is given by:

$$
\epsilon_{s}=\frac{s_{s}}{G}=\frac{F_{n}}{2 l G}
$$

where:

$G$ represents the modulus of elasticity in shear and is equal to: $\frac{E}{2(1+\mu)}$. The total deflection, $e_{t}$, for both threads is twice that for one thread. Since the dellection of one thrcad is $c_{s}\left(\frac{c}{2}\right)$, the deflection for bonth threads would be expressed as: 


$$
e_{t}=2 \epsilon_{s}\left(\frac{c}{2}\right)=\epsilon_{s} c
$$

where:

c represents the depth of the thread.

Therefore:

$$
e_{t}=\frac{F_{n} c}{2 \ell G}=\frac{F_{n} 2(1+\mu) c}{2 \ell E} .
$$

The thread load, $F_{n}$, for each thread may be derived by substituting into Equation 1 the values from Equations $4 a, 7 a$, and 10a, thus:

$$
\begin{aligned}
& e_{t}=e_{s}-e_{p}, \text { or } \\
& \frac{F_{n}(1+\mu) c}{l E}=\left(P_{1}-\sum F_{n-1}\right) \frac{Q L}{E}+\left(\sigma_{i}-\frac{\sum F_{n-1} 2 R}{b^{2}}\right) \frac{b^{2}}{a^{2}} \frac{L}{E}, \text { or } \\
& \frac{F_{n}(1+\mu) c}{\ell L}=\left(Q P_{1}+\frac{b^{2}}{a^{2}} \sigma_{i}\right)-\sum F_{n-1}\left[Q+\left(\frac{2 R}{b^{2}}\right) \frac{b^{2}}{a^{2}}\right] \text {, and } \\
& F_{n}=\frac{l L}{(1+\mu) c}\left[\left(Q P_{1}+\frac{b^{2}}{a^{2}} \sigma_{i}\right)-\Sigma F_{n-1}\left(Q+\frac{2 R}{b^{2}} \cdot \frac{b^{2}}{a^{2}}\right)\right] \text {. }
\end{aligned}
$$

Thread-Load Calculation for Pressure Vessel I (ruptured vessel)

Use Figure 9 for the following dimensional definitions:

$$
\begin{aligned}
& a=24.01 \text { inches, } \\
& b=15.00 \text { inches, } \\
& c=0.994 \text { inch, } \\
& R=24.55 \text { inches, } \\
& P_{1}=137,000 \mathrm{lbs} / \text { linear inch of circumference (at the pitch line), } \\
& r^{2}=5.15 \mathrm{in}^{2},
\end{aligned}
$$


$K$ represents the portion of the total moment carried by the thread section of the shell $(8)=0.505$,

$$
\begin{aligned}
& \mu=0.3, \\
& l=\frac{\mathrm{L}}{2}=\frac{1.5}{2}=0.75 \mathrm{inch}(\text { clearance included }), \\
& a^{2}=577 \mathrm{in}^{2}, \\
& b^{2}=225 \mathrm{in}^{2}, \\
& A=9.337 \mathrm{in}^{2}, \\
& w=4.69 \text { inches, }^{2} \\
& y_{1}=4.145 \text { inches, }
\end{aligned}
$$

$k$ represents the stress concentration factor $(4)=3.5$,

$Q=\frac{1}{A}\left(1+\frac{K w y_{1}}{r^{2}}\right)$,

$Q=0.311$,

$$
\begin{aligned}
& Q P_{1}=0.311(137,000)=42,600, \text { and } \\
& \sigma_{P_{1}}=\frac{b^{2}}{a^{2}} \sigma_{i}-11,700 \mathrm{psi} .
\end{aligned}
$$

Substituting in Equation $11 \mathrm{~b}$ gives:

$$
F_{n}=47,300-0.344 \sum F_{n-1}
$$

The thread load, F, for the first thread would be:

$$
F_{1}=47,300 \mathrm{lbs} / \text { /inear inch (Table 1). }
$$


Table 1

THREAD LOADS FOR PRESSURE VESSEL I

$\left(F_{n}=47,300-0.344 \Sigma F_{n-1}\right)$

\begin{tabular}{cccr}
\hline $\begin{array}{c}\text { Thread } \\
\text { Number }\end{array}$ & $F_{n-1}$ & $0.344 \sum F_{n-1}$ & $F_{n}$ \\
\hline 1 & & & 47,300 \\
2 & 47,300 & 16,300 & 31,000 \\
3 & 78,300 & 26,900 & 20,400 \\
4 & 98,700 & 33,900 & 13,400 \\
5 & 112,100 & 38,600 & 8,700 \\
6 & 120,800 & 41,600 & 5,700 \\
7 & 126,500 & 43,500 & 3,800 \\
8 & 130,300 & 44,800 & 2,500 \\
9 & 132,800 & 45,700 & 1,600 \\
10 & 134,400 & 46,200 & 1,100 \\
11 & 135,500 & 46,600 & 700 \\
12 & 136,200 & 46,900 & 400 \\
13 & 136,600 & 47,000 & 300 \\
14 & 136,900 & & \\
& & & \\
& Correction Factor $=\frac{137,000}{136,900}=1.001$ (not significant) & \\
\hline
\end{tabular}

Thread-Load Calculation for Pressure Vessel II (twin vessel)

Use. Figure 9 for the following dimensional definitions:

$$
\begin{aligned}
& a=20.48 \text { inches, } \\
& b=15.03 \text { inches, } \\
& c=0.994 \text { inch, } \\
& r^{2}=11.1 \mathrm{in}^{2},
\end{aligned}
$$

$\mathrm{K}$ represents the portion of the total moment carried by the thread section of the shell $(8)=0.63$,

$$
\mu=0.3 \text {, }
$$

$P_{1}=162,000 \mathrm{lbs} /$ linear inch of circumference (at the pitch line),

$k$ represents the stress concentration factor $(4)=3.7$,

$\ell=\frac{L}{2}=\frac{1.5}{2}=0.75$ (clearance included),

$R=21.02$ inches, 


$$
\begin{aligned}
A & =15.1 \mathrm{in}^{2}, \\
w & =6.82 \text { inches, } \\
y_{1} & =6.25 \text { inches, } \\
Q & =\frac{1}{A}\left(1+\frac{K w y_{1}}{r^{2}}\right), \\
Q & =0.227, \\
Q P & =36,800 \text { psi, and } \\
\sigma_{P_{1}} & =\frac{h^{2}}{a^{2}} \sigma_{i} \equiv 16,200 \mathrm{ps} 1 .
\end{aligned}
$$

From Equation 11b:

$$
F_{n}=46,200-0.284 \sum F_{n-1}
$$

The thread load for the first thread would be:

$$
F_{1}=46,200 \mathrm{lbs} / \text { linear inch at a 30,000-psi internal pressure (Table 2). }
$$

Table 2

THREAD LOADS FOR PRESSURE VESSEL II

$$
\left(F_{n}=46,200-0.284 \sum F_{n-1}\right)
$$

\begin{tabular}{cccr}
\hline $\begin{array}{c}\text { Thread } \\
\text { Number }\end{array}$ & $F_{n-1}$ & $0.284 \Sigma F_{n-1}$ & $F_{n}$ \\
\hline 1 & & 0 & 46,200 \\
2 & 46,200 & 13,100 & 33,100 \\
3 & 79,300 & 22,500 & 23,700 \\
4 & 103,000 & 29,300 & 16,900 \\
5 & 120,000 & 34,100 & 12,100 \\
6 & 132,100 & 37,500 & 8,700 \\
7 & 140,800 & 40,000 & 6,200 \\
8 & 147,000 & 41,700 & 4,500 \\
9 & 151,500 & 43,000 & 3,200 \\
10 & 154,700 & 43,900 & 2,300 \\
11 & 157,000 & 44,600 & 1,600 \\
12 & 158,000 & 45,000 & 1,200 \\
13 & 159,800 & 45,400 & 800 \\
14 & 160,600 & 45,600 & 600 \\
15 & 161,200 & 45,800 & 400 \\
16 & 161,600 & 45,900 & 300 \\
& & & \\
& Correction Factor & 162,000 & 161,600 \\
\end{tabular}


Thread Internal Stress (Boussinesq shear stress method)

First Thread Internal Stress for Pressure Vessel I (ruptured vessel) -

$$
\text { Shear stress }(9)=\tau(\max )=0.368 \mathrm{~S}_{b} \text {, }
$$

where:

$S_{b}$ represents the bearing stress over the bearing width of the thread.

$$
\text { Equivalent uniaxial stress }(10)=S_{a}=\frac{0.368 S_{b}}{\sqrt{2} / 3} .
$$

Assuming parabolic pressure distribution:

$$
\begin{gathered}
S_{b} \text { (max) }=2 \times S_{b} \text { (ave), } \\
S_{b} \text { (ave) }=\frac{\text { thread load }}{\text { bearing width }}=\frac{47,300}{0.838}=56,500 \text { psi, } \\
S_{b}(\text { max })=2 \times 56,500=113,000 \text { psi, and } .
\end{gathered}
$$

Equivalent uniaxial, $S_{a}=0.781(113,000)=88,200$ psi.

Life at a 30,000 -psi pressure estimated at 800 cycles. (1)

First Thread Internal Shear Stress for Pressure Vessel II (twin vessel) -

$$
\begin{gathered}
S_{b} \text { (ave) }=\frac{46,200}{0.838}=55,100 \text { psi, } \\
S_{b}(\max )=2 \times 55,100=110,200 \text { psi, } \\
S_{a}=0.781(110,200)=86,100 \text { psi (at a 30,000-psi pressure), or } \\
=64,600 \text { psi (at a } 22,500 \text {-psi pressure). } \\
\text { Life at 30,000-psi pressure }=800 \text { cycles. }(1) \\
\text { Life at } 22,500 \text {-psi pressure }=2,000 \text { cycles. }(1)
\end{gathered}
$$


Shell Tensile Stress at the First Thread (direct-plus-bending stress method)

Pressure Vessel I (ruptured vessel) -

where:

$$
\sigma_{z_{1}}=\frac{P_{1}}{A}+\frac{M_{1} y_{1}}{i}
$$

$$
K=0.505
$$

where:

$$
\begin{gathered}
\sigma_{z_{1}}=\frac{P_{1}}{A}\left(1+\frac{K w y_{1}}{2}\right), \\
\sigma_{z_{1}}=42,500 \text { psi, } \\
s_{z_{1}}=k(42,500)=3.5(42,500),
\end{gathered}
$$

$k$ represents the stress concentration factor $(4)=3.5$, and

$S_{z_{1}}$ the stress range (longitudinal) at the first thread.

Therefore:

$$
\begin{gathered}
S_{z_{1}}=149,000 \text { psi (at a } 30,000 \text {-psi pressure), and } \\
S_{a}=\frac{149,000}{2}=74,500 \text { psi. }
\end{gathered}
$$

Life at a 30,000-psi operating pressure estimated as 1,300 cycles. (1)

Pressure Vessel II (twin vessel) -

$$
\sigma_{z_{1}}=\frac{P_{1}}{A}+\frac{M_{1} y_{1}}{1},
$$

where:

$$
K=0.63
$$




$$
\begin{gathered}
\sigma_{z_{1}}=\frac{P_{1}}{A}\left(i+\frac{K w y_{1}}{r^{2}}\right), \\
\sigma_{z_{1}}=36,800 \mathrm{psi}, \\
S_{z_{1}}=k(36,800)=3.7(36,800),
\end{gathered}
$$

where:

$$
\begin{aligned}
& k \text { represents the stress concentration factor }(4)=3.7 \text {, and } \\
& \mathrm{S}_{\mathrm{z}_{1}} \text { the stress range (longitudinal) at the first thread. }
\end{aligned}
$$

Therefore:

$$
\begin{aligned}
& S_{z_{1}}=137,000 \text { psi (at a 30,000-psi operating pressure), or } \\
& S_{z_{1}}=\frac{22,500}{30,000}(137,000)=103,000 \text { psi (at a 22,500-psi operating pressure), and } \\
& S_{a}=\frac{103,000}{2}=51,500 \text { psi. }
\end{aligned}
$$

Life at a 22,500-psi operating pressure estimated as 5,000 cycles. (1)

\section{EXPERIMENTAL STRAIN GAGE ANALYSIS}

\section{Preface}

It was postulated that if actual strain at the root of the first thread of the twin vessel could be measured under operating conditions, certain failure modes could be predicted. Subsequent investigation indicated that miniature strain gages could be installed. (11)

The 0.156 -inch clearance space at the root of the thread was sufficient area for installing a gage that was $50 \mathrm{mils}$ long and 44 mils wide. The seven-inch undercut above the thread and the existing $1 / 2$-inch-diameter bleeder hole in the lower plug provided wiring access for this experiment (see Figures 10 and 11).(12) 

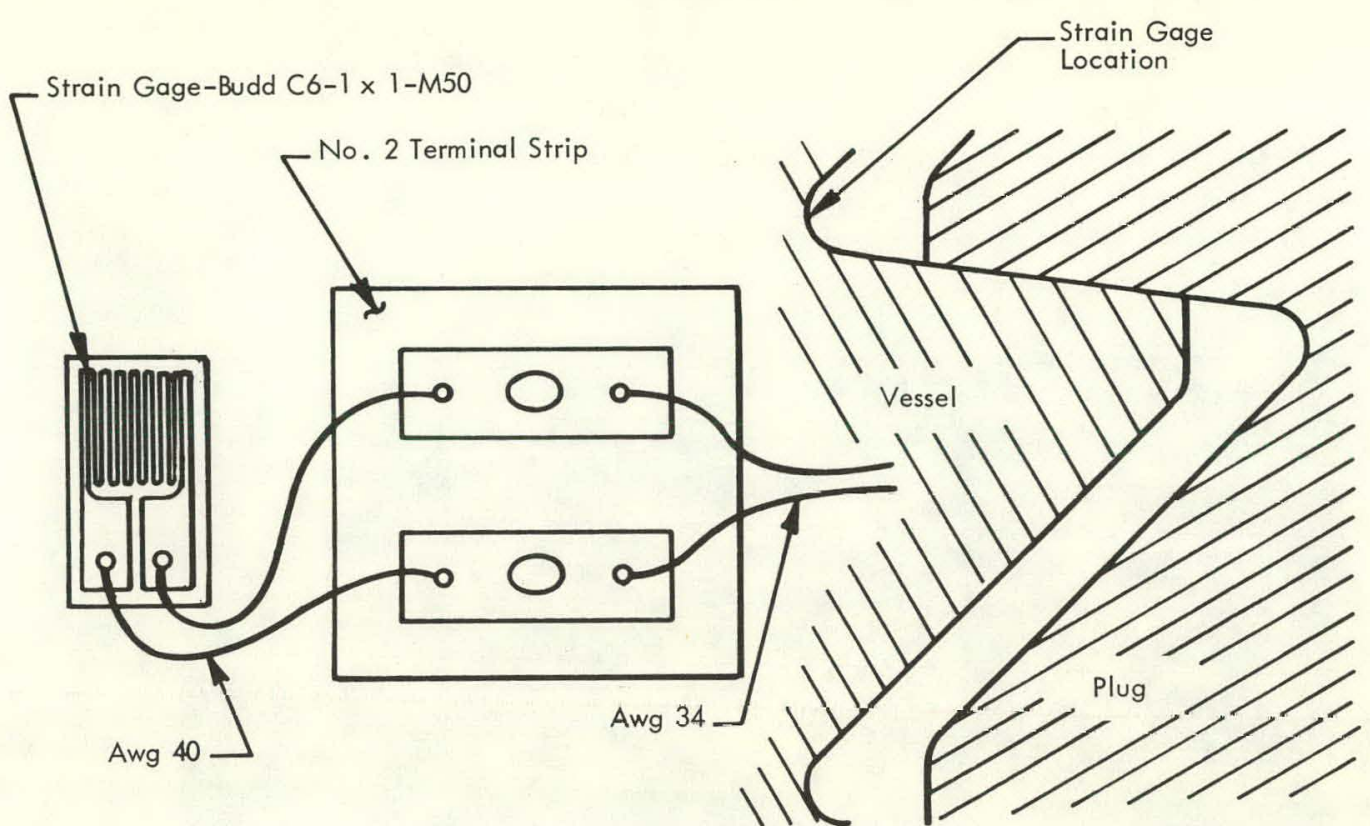

Thread Cross Section Detail $2.8 \mathrm{X}$

137812

Figure 10. TYPICAL THREAD ROOT INSTALLATION.

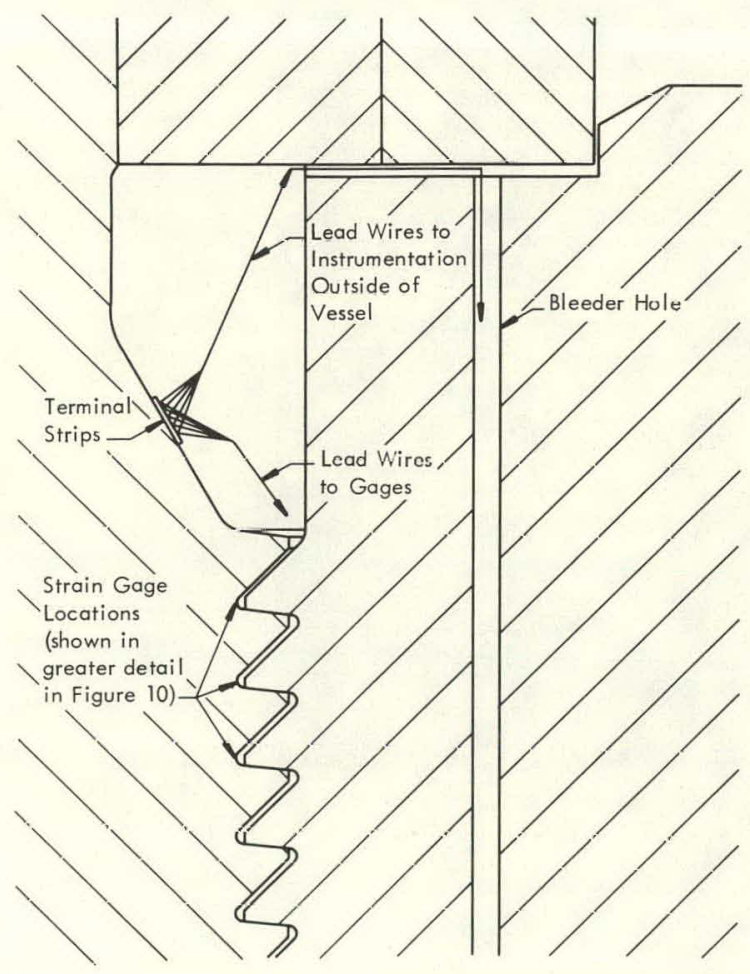

137813

Figure 11. PLUG MATING TO THE END OF THE PRESSURE VESSEL.

\section{Installation of the Gages}

A full-size thread and ring mockup was used to train a technician in the installation of the gages, terminals, and wires. Special tools and several weeks of training with the mockup were necessary before the vessel installation was made. The typical thread installation shown in Figures 12 and 13 resulted. A Budd C6-1 $\times 1-M 50$ strain gage and a Type 2 glass-epoxy-laminated-backed terminal were used with Size AWG 40 enameled copper wire between the gage and terminal strip. Size AWG 34 enameled copper wire was used between the Type 2 and Type 4 terminal strips located in the undercut cavity above the thread. Size AWG 22 wire was used from the Type 4 terminal strip through the four bleeder holes to the outside of the vessel (see Figures 11 and 14 through 16). 


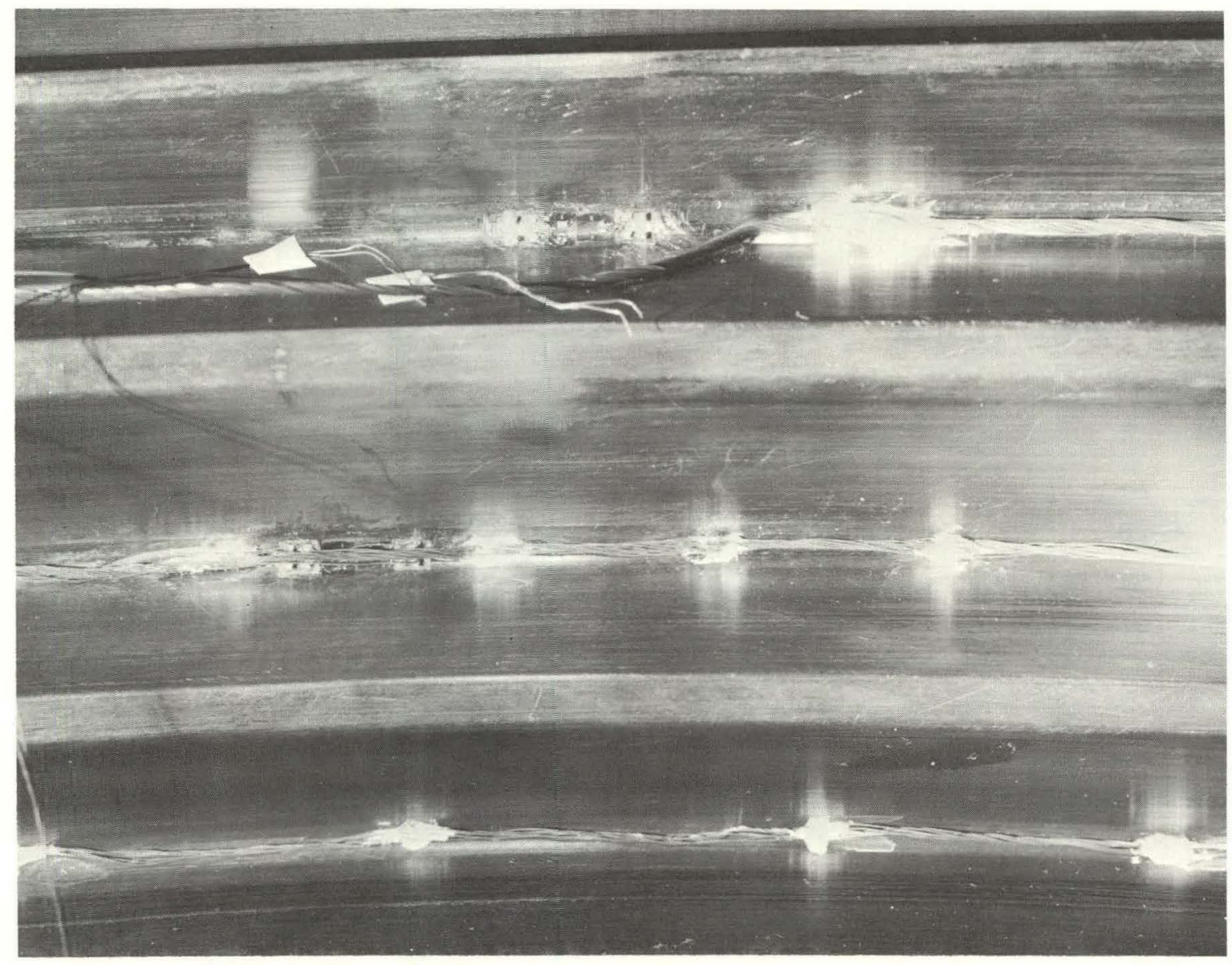

112411

Figure 12. TYPICAL GAGE ATTACHMENT. 


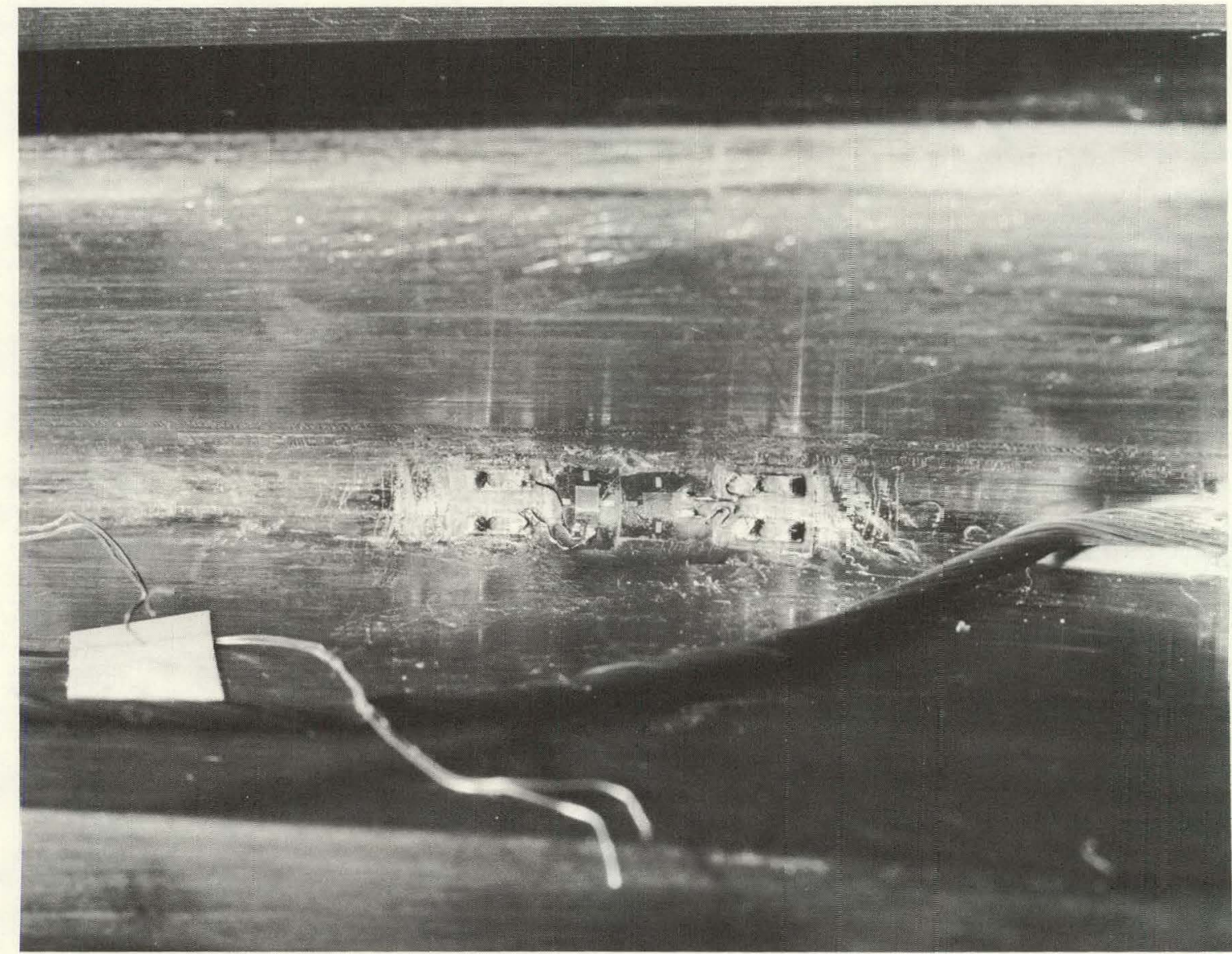

112412

Figure 13. ENLARGED VIEW OF A TYPICAL GAGE ATTACHMENT.. 


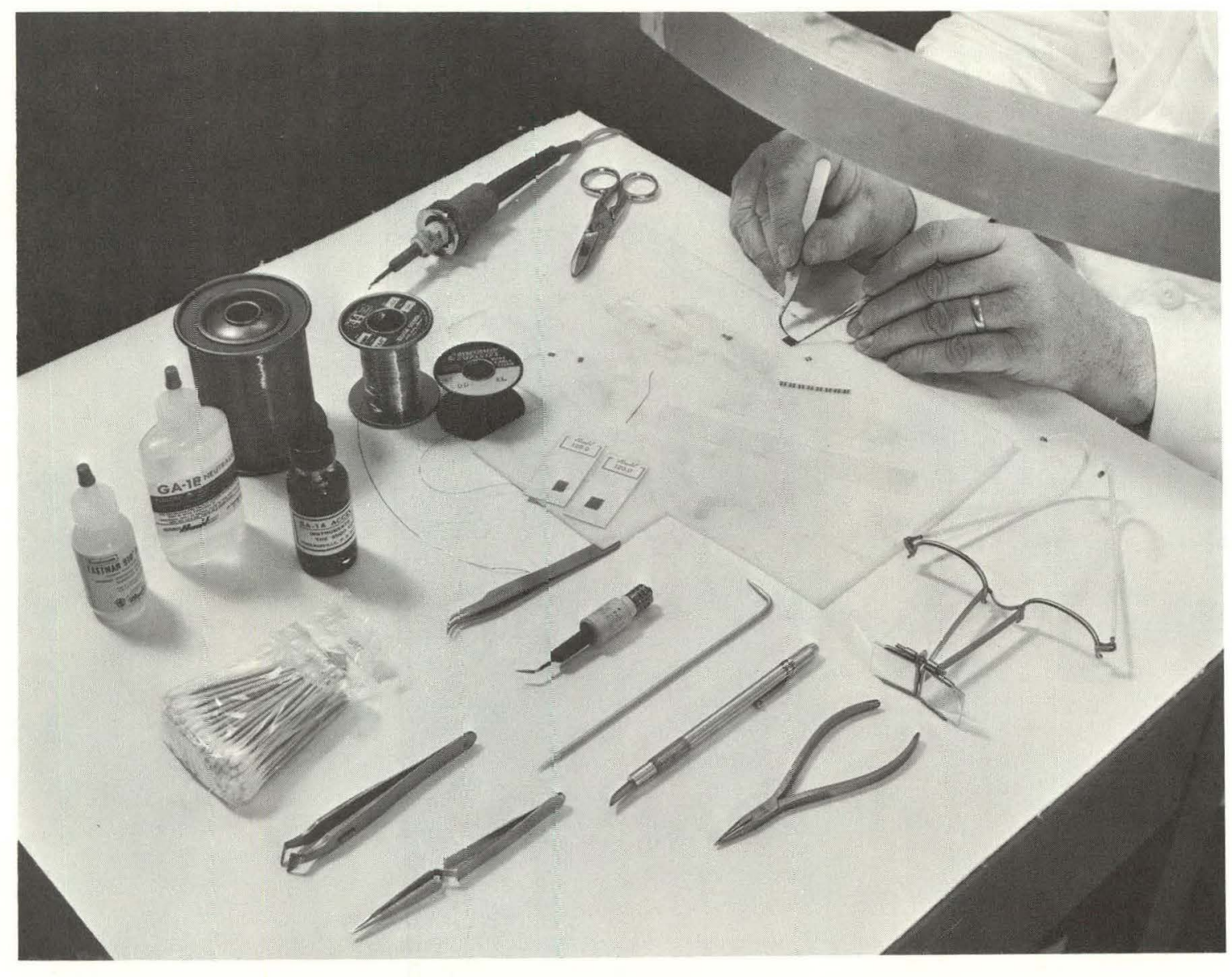

112414

Figure 14. TOOLS AND MATERIIALS USED FOR GAGE INSTALLATION. 


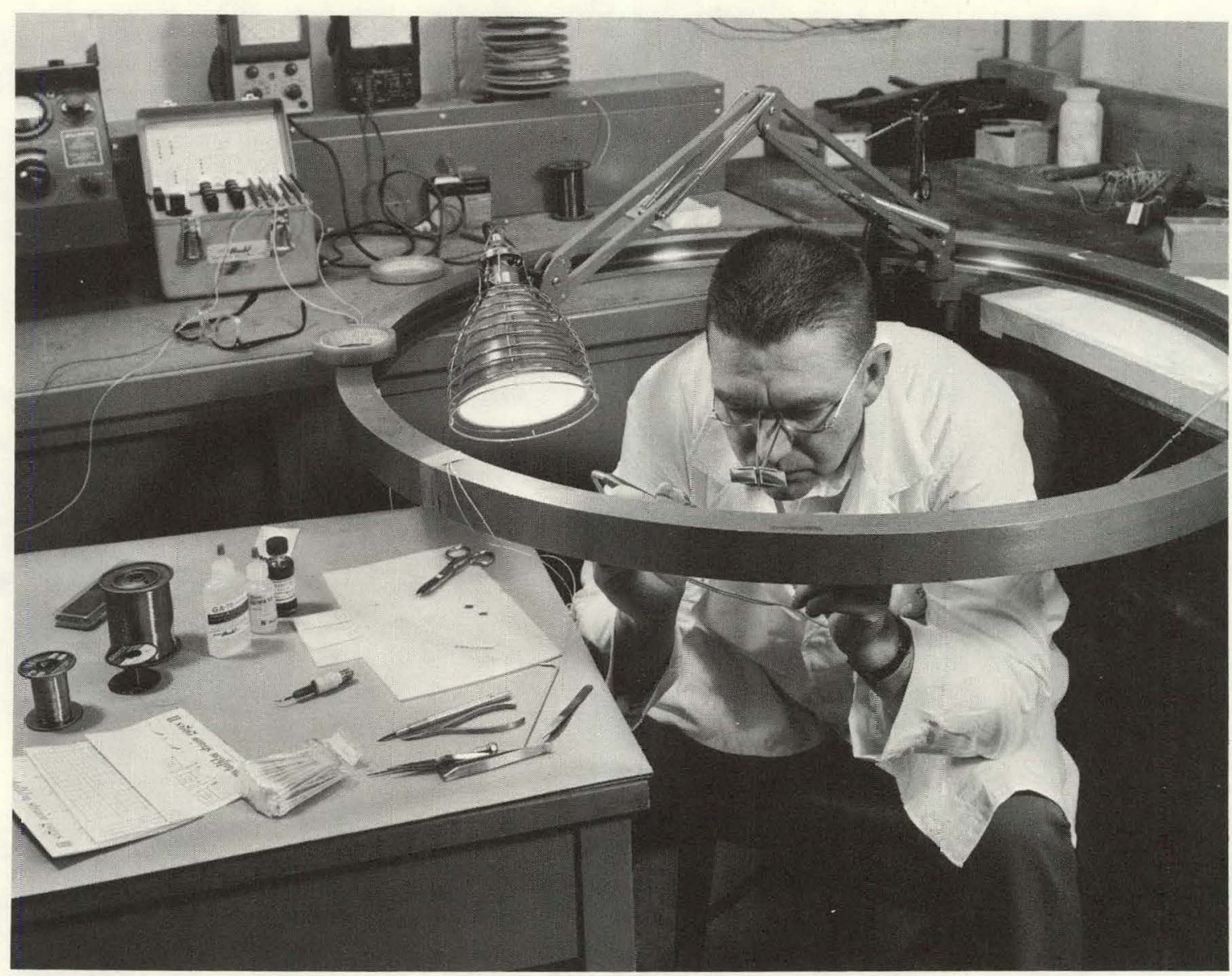

112415

Figure 15. PRACTICE RING FOR GAGE INSTALLATION. 


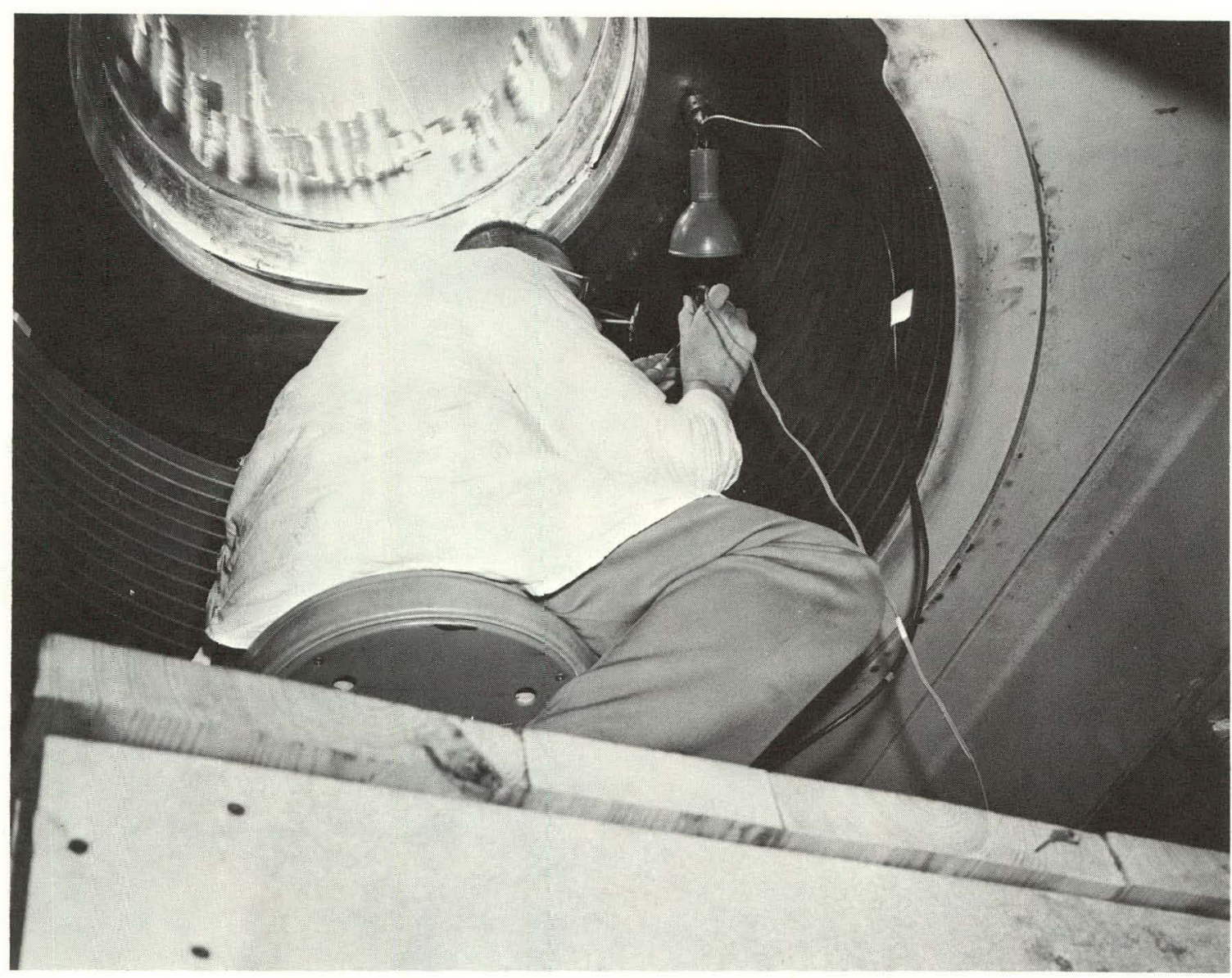

112410

Figure 16. ACTUAL GAGE INSTALLATION. 
Twenty strain gages were installed in the first three thread roots. Ten gages were for longitudinal strain readings and ten were for circumferential strain measurements. Five pairs of gages (longitudinal and circumferential) were installed in the first thread root, three pairs in the second, and two pairs in the third (Figure 17). This arrangement required that a bundle of lead wires exit into the cavity above the thread. The gages, terminal strips, and wires were cemented to the shell with 910 adhesive. The standard acceptable procedure of pretinning the leads and dry-iron soldering was used. All the gages and terminals were water-proof coated with GW-1 and then covered with two thin coats of shellac.

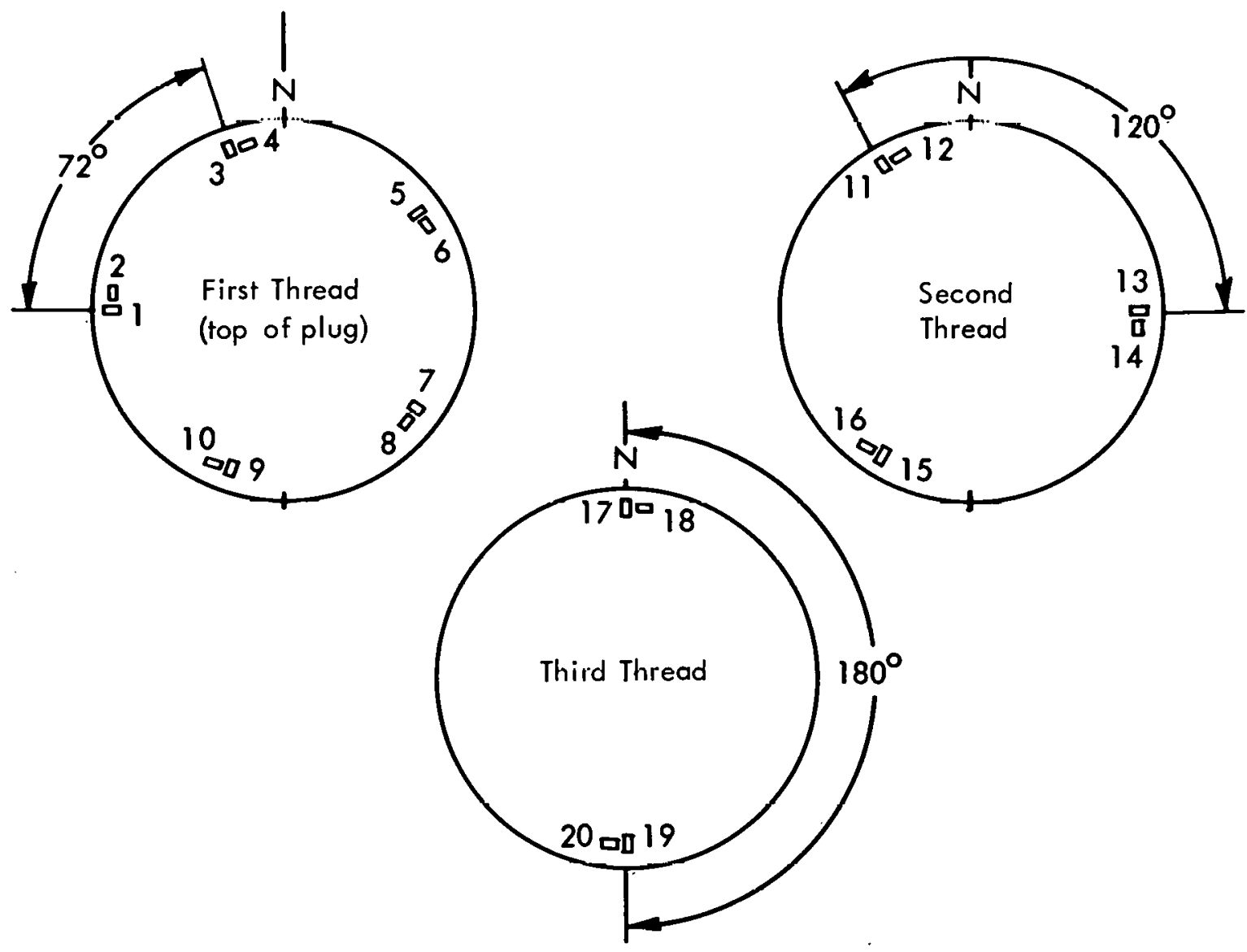

137811

Figure 17. GAGE LOCATIONS IN THE THREE TEST THREADS. (Odd Numbers are Longitudinal Gages; Even Numbers are Circumferential Gages)

The plug was inserted until three turns remained. The technician then entered the vessel from the top, fed the leads through the bleeder holes, and wrapped three turns around the plug, allowing the wire to unwind into the cavity above the thread as the plug was turned into its final position (see Figure 11). 
Obtaining the Strain Data

Two commercially available Baldwin SR-4 strain indicators, with ten-channel switching and balancing units, were used in obtaining the strain data.

A series of readings, at various pressures from zero to 22,500 psi, were taken (recorded in Table 3). (11)

$\underline{\text { Strain Gage Data Results }}$

The lower closure plug lacked full engagement by one-sixth turn; therefore, the data from Gage 1 were not considered in the strain average since that location was not under full load.

Readings from the longitudinally installed gages (Gages 3, 5, 7, and 9) in the first thread root were averaged, giving a value of 3,094 microinches per inch at a 22,500-psi pressure. The maximum range of stress (see Table 3 ) was computed using the method of Singer: (13)

$$
\begin{aligned}
\text { Maximum longitudinal stress }=S_{y} & =\frac{E}{1-\mu .}\left(e_{y}+\mu e_{x}\right), \text { or } \\
& =\frac{30,000,000}{0.91}\left(3,094 \times 10^{-6}\right) \text {, or } \\
S_{y} & =102,000 \text { psi (at a } 22,500 \text {-psi pressure), }
\end{aligned}
$$

where:

$$
\begin{aligned}
& \text { E represents the modulus of elasticity }\left(30 \times 10^{6} \mathrm{psi}\right) \text {, } \\
& \mu \text { Poisson's ratio }(0.3), \\
& e_{y} \text { the longitudinal strain, and } \\
& e_{x} \text { the tangential strain (considered negligible). } \\
& S_{y} \text { is equivalent to } S_{z} \text {. }
\end{aligned}
$$

This value compares with the 103,000-psi stress range obtained by calculation by the direct-plus-bending stress method. 
Table 3

RECORDED STRAIN LEVELS ON THE THIRTY-INCH PRESSURE VESSEL (All Readings Are in Microinches Per Inch)

\begin{tabular}{|c|c|c|c|c|c|c|c|c|c|c|c|c|c|c|c|}
\hline \multirow{2}{*}{$\begin{array}{l}\text { Gage } \\
\text { Number }\end{array}$} & \multicolumn{14}{|c|}{ Pressure Level (psi) } & \multirow{2}{*}{$\begin{array}{l}\text { Maximum } \\
\text { Correcteo }\end{array}$} \\
\hline & Zero & 5,000 & 10,000 & Zero & 5,000 & 10,000 & 12,000 & 14,000 & 16,000 & 18,000 & 20,000 & 21,000 & 22,500 & Zero & \\
\hline 1 & 0 & 220 & 480 & 20 & 250 & 470 & 580 & 680 & 760 & 860 & 950 & 1,000 & 1,060 & -10 & 1,250 \\
\hline 2 & 0 & 10 & 20 & 30 & -20 & 20 & 30 & 30 & 40 & 50 & 50 & 40 & 40 & -10 & 47 \\
\hline 3 & 0 & 920 & 1,490 & 10 & 860 & 1,500 & 1,740 & 2,020 & 2,190 & 2,430 & 2,660 & 2,770 & 2,940 & -30 & 3,470 \\
\hline 4 & 0 & 0 & 20 & 20 & -20 & 10 & 30 & 30 & 40 & 40 & 40 & 50 & 40 & -10 & 47 \\
\hline 5 & 0 & 510 & 1,080 & 10 & 530 & 1,070 & 1,320 & 1,600 & 1,780 & 2,010 & 2,260 & 2,370 & 2,540 & $\dot{0}$ & 2,995 \\
\hline 6 & 0 & 10 & 30 & 20 & 0 & 30 & 40 & 50 & 60 & 50 & 60 & 60 & 60 & -10 & 70 \\
\hline 7 & 0 & 560 & 1,130 & 10 & 590 & 1,130 & 1,400 & 1,710 & 1,870 & 2,110 & 2,380 & 2,500 & 2,670 & -10 & 3,150 \\
\hline 8 & 0 & 60. & 90 & 70 & 0 & 80 & 90 & 100 & 100 & 110 & 110 & 110 & 110 & 0 & 130 \\
\hline 9 & 0 & 960 & 1,400 & -10 & 990 & 1,400 & 1,590 & 1,760 & 1,880 & 2,020 & 2,170 & 2,240 & 2,340 & -20 & 2,760 \\
\hline 10 & 0 & -20 & 10 & -10 & -10 & 20 & 10 & 20 & 30 & 40 & 40 & 40 & 40 & 0 & 47 \\
\hline 11 & 0 & -25 & 60 & 0 & -120 & 60 & 170 & 310 & 410 & 530 & 660 & 720 & 820 & 0 & 970 \\
\hline 12 & 0 & -10 & 30 & -10 & 10 & 40 & 40 & 50 & 50 & 61) & 60 & 60 & 70 & 0 & 83 \\
\hline 13 & 0 & 580 & 840 & -10 & 620 & 860 & 960 & 1,070 & 1,150 & 1,250 & 1,350 & 1,400 & 1,470 & 0 & 1,735 \\
\hline 14 & 0 & -10 & 20 & -10 & 10 & 40 & 40 & 50 & 50 & 60 & 60 & 60 & 70 & 0 & 83 \\
\hline 15 & 0 & -510 & -480 & -10 & 510 & 530 & 560 & 610 & 630 & 660 & 700 & 710 & 740 & -5 & 875 \\
\hline 16 & 0 & -40 & 20 & -10 & 20 & 30 & 30 & 40 & 40 & 50 & 50 & 50 & 60 & 0 & 70 \\
\hline 17 & 0 & 450 & 790 & 0 & 470 & 790 & 910 & 1,050 & 1,130 & 1,250 & 1,380 & 1,430 & 1,500 & -10 & 1,770 \\
\hline 18 & 0 & 20 & 50 & 0 & 20 & 40 & 50 & 50 & 50 & 60 & 70 & 70 & 70 & -10 & 83 \\
\hline 19 & 0 & 340 & 600 & 0 & 350 & 600 & 710 & 830 & 900 & 1,000 & 1,100 & 1,135 & 1,190 & -10 & 1,400 \\
\hline 20 & 0 & 0 & 30 & 0 & 0 & 30 & 30 & 40 & 40 & 50 & 50 & 55 & 50 & -10 & 60 \\
\hline
\end{tabular}




\section{CONCLUSIONS AND RECOMMENDATIONS}

The following conclusions and recommendations can be made as a result of this work:

1. It has been concluded that fatigue life can be predicted for pressure vessels with threaded closures of uniform cross section. Calculated stress values and experimental strain-gage analyses for the highly stressed thread-root locations are comparable and applicable when using correctly determined thread loads and stress concentration factors in conjunction with the Design Fatigue Curve from ASME Section VIII, Division 2, Figure 5-110.1 .

2. For an isostat having a 30-inch inside diameter and a 120-inch inside depth, and to operate at 30,000 psi with optimum safety, a yoke-supported closure design is recommended. Cost and safety consideration studies have been made at $Y-12$ and they have indicated that a yoke-supported closure design is preferred for pressure vessels exceeding a 9,000-ton closure load, or when the load exceeds 900 tons per foot of inside depth. Figures 18 and 19 present views of a yokesupported pressure vessel. The twin vessel ( $P V$ II) was subsequently modified to a gas autoclave for use at reduced pressures. (14)

3. In the selection of materials of construction for pressure vessels, it is recommended that the nil-ductility temperature (NDT) of the material should be below the operating temperature, preferably by at least $10^{\circ} \mathrm{F}$. These values should be obtained from specimens of the forgings or plates to be used in fabricating the pressure vessel assembly and should be certified by the supplier.

4. For checking the stresses of the threaded closures, it is recommended that consideration be given to obtaining strain-gage data from the thread root and other stress-concentrated areas, and provisions should be incorporated in the design for leadthroughs from the gages. Obtaining this strain-gage data can be a requirement for acceptance of the pressure vessel.

5. Strain-gage data obtained at a partial thread, or at a thread not fully engaged, or from adjacent areas to the threads, are not representative of the strain at the root of a fully loaded thread. Unfounded conclusions might be made by using such values.

6. There is a definite need for safety standards for the installation and construction of high-pressure-systems facilities. High-pressure systems (those operated at 3,000 psi or greater) are becoming more numerous in industry. The existing ASME and state codes and standards are only a beginning. They do not adequately cover shielding, barricading, instrumentation, operations, and maintenance. 


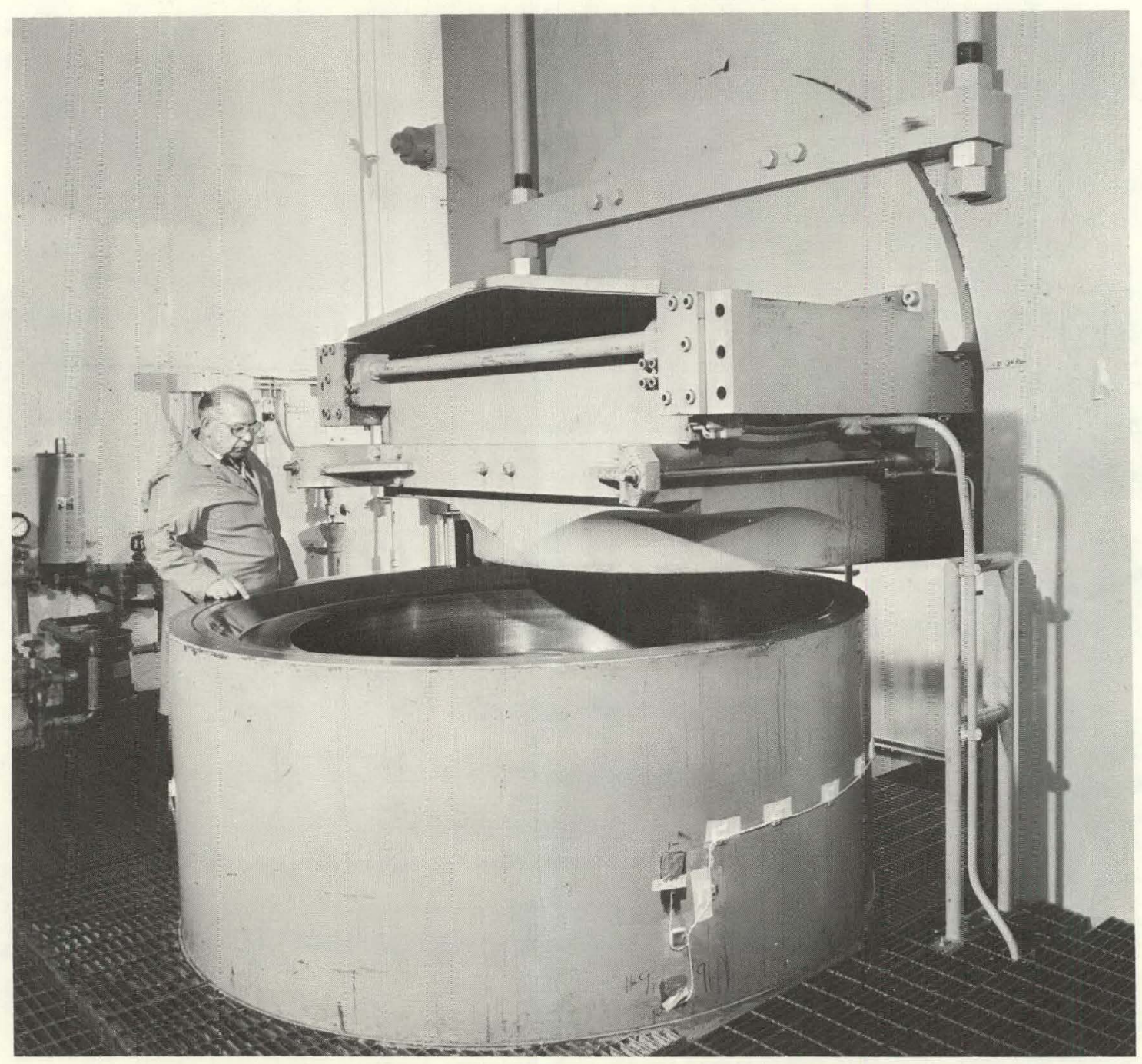

120738

Figu-e 18. YOKE-SUPPORTED CLOSURE FOR THE 60-INCH PRESSURE VESSEL. 


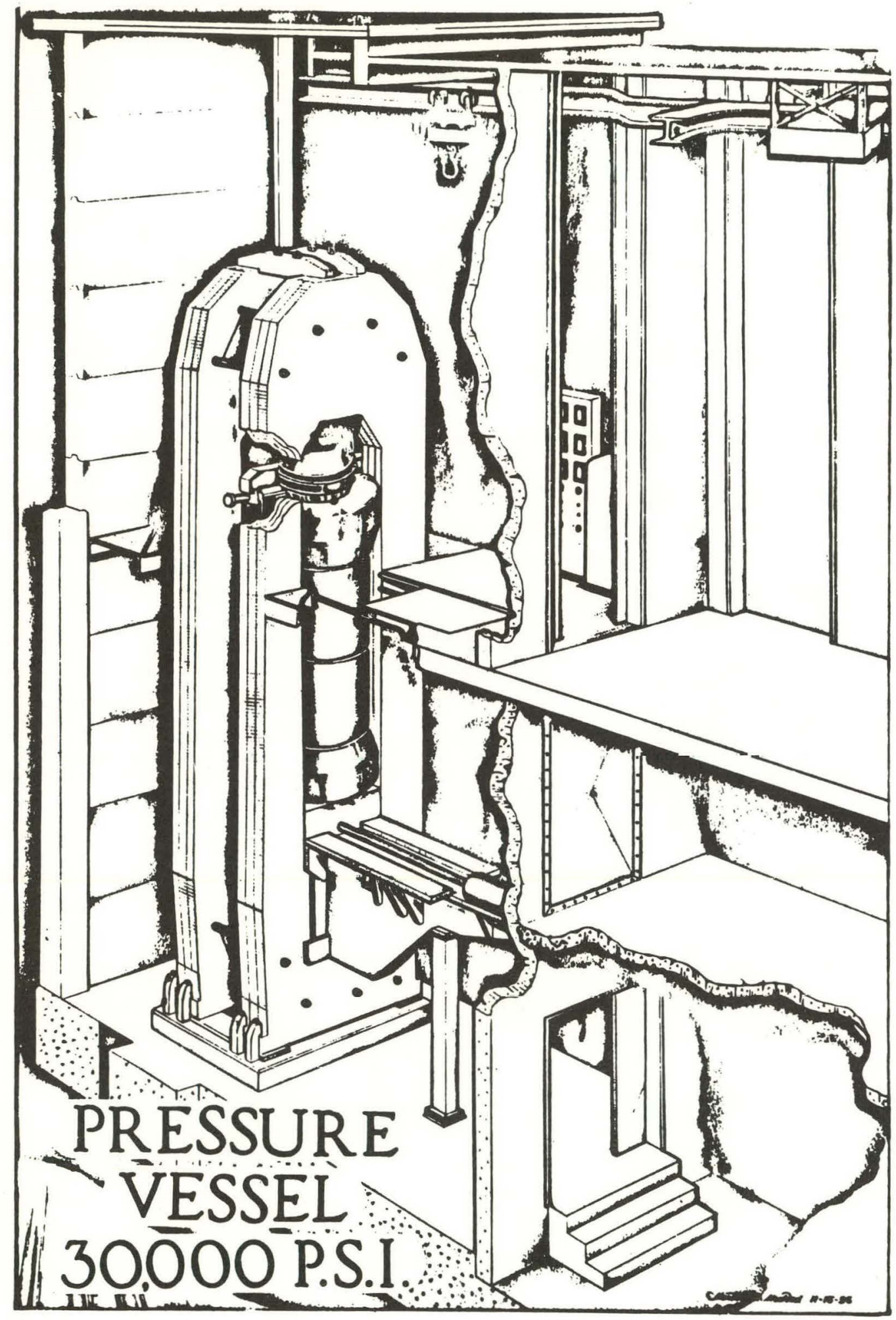

137809

Figure 19. YOKE-SUPPORTED CLOSURE FOR THE 30-INCH PRESSURE VESSEL. (Pressure Vessel II) 


\section{REFERENCES}

(1) ASME Boiler and Pressure Vessel Code Section VIII; Pressure Vessels-Division 2, Figure 5-110.1; American Society of Mechanical Engineers, United Engineering Center, New York, NY (1968).

(2) Sturm, R. G.; Consultant, Huntsville, Alabama; Member PVRC, ASME, and SESA.

(3) Report of Auburn Research Foundation, Oak Ridge Photoelasticity Studies; March 31, 1959.

(4) Peterson, R. E.; Stress Concentration Design Factors, Figure 33; John Wiley and Sons, Inc, New York, NY (1953).

(5) Templin, R. L. and Sturm, R. G.; Some Stress-Strain Studies of Metals; Aluminum Company of Arnerica; IAeS; January 25, 1940.

(6) Long, P. J. and Groothuis, S. E.; Strain Gage Measurement of Shock Loading on the Thirty-Inch Pressure Vessel (PV II), Y-B93-2; Union Carbide Corporation-Nuclear Division, Oak Ridge Y-12 Plant, Oak Ridge, Tennessee.

(7) Timoshenko, S.; "Strength of Materials, Part II", Advanced Theory and Problems, Second Edition, p 32, et seq; D. Van Nostrand Company, Inc.

(8) Timoshenko, S. and Woinosky-Krieger, S.; Theory of Plates and Shells, Second Edition, pp 466-474; McGraw-Hill Book Company, Inc, New York, NY.

(9) Nadai, A.; Theory of Flow and Fracture of Sulids, II, Second Edition, p 198, et seq; Mc Graw-Hill Book Company, Inc, New York, NY.

(10) Nadia, A.; Theory of Flow and Fracture of Solids, 1, Second Edition, p 99, et seq; Mc Graw-Hill Book Company, Inc, New York, NY.

(11) Long, P. J. and Ross, W. D.; Strain Gage Test at the Threaded Closure on a Thirty-Inch Pressure Vessel, $Y-1471$, Union Carbide Corporation-Nuclear Division, Oak Ridge Y-12 Plant, Oak Ridge, Tennessee.

(12) Pohto, H. A.; Testing Procedure and Test Gage Installation for Isostats in the Y-12 Plant, Y-EA-45; Union Carbide Corporation-Nuclear Division, Oak Ridge $Y-12$ Plant, Oak Ridge, Tennessee 
(13) Singer, F. L.; Strength of Materials, Second Edition, $p$ 38; Harper and Row, Publishers, New York, NY.

(14) Pohto, H. A. and St Onge, C. D.; Mechanical Design Criteria and Analyses for Converting PV II to a Gas Autoclave, Compendium of Gas Autoclave Engineering Studies, Edited by C. E. Muzzall, Y-1478; Union Carbide Corporation-Nuclear Division, Oak Ridge Y-12 Plant, Oak Ridge, Tennessee. 


\section{ACKNOWLEDGEMENTS}

The author wishes to thank R. G. Sturm, a consultant for the $Y-12$ Plant on the original calculated post-failure analysis, for his guidance and assistance. He has given permission to include, as a part of this report, the explanation of the Sturm method for calculating individual thread loads for pressure vessels with threaded closures. 